Western Governors'

Conference

Food in the West

\title{
FOOD IN THE WEST
}



Western Governors' Conference 
MONTANA STATE LIBRARY Food in w $W_{0}$ 1982? $\mathrm{C}$



30864000702889 
Food in the West 


\section{Contents}

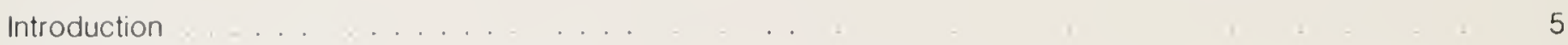



Section One - Food in the West Plenary Session

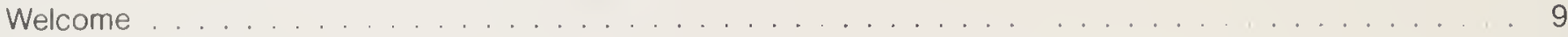

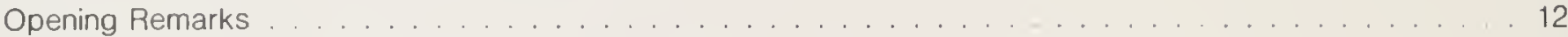

Panel Discussion:

Dr. Emery N. Castle . . . . . . . . . . . . . . . . . . . . . . . . . . . . . . . . . . . 15

Resources for the Future, Inc.

Burlington Northern Inc.

Dr. Norman E. Borlaug . . . . . . . . . . . . . . . . . . . . . . . . . . . . . . 25

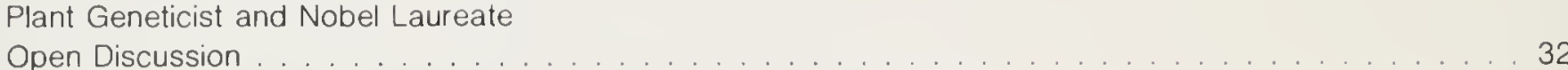



Section Two - Food in the West Prepared Reports

Toward a Western Agricultural Policy . . . . . . . . . . . . . . . . . . . . . . . . . . . 43

John Ehrenreich



E. Wayne Hage

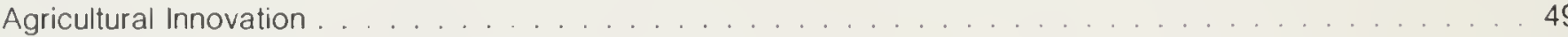

John Freivalds

Cooperative Marketing: Aggressive, Innovative . . . . . . . . . . . . . . . . . . . . . . 51

Randall E. Torgerson

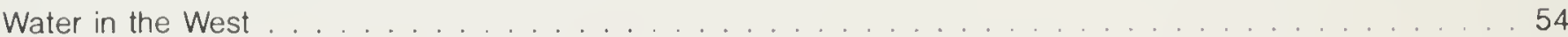

John R. Lassen

Food From Rangeland . . . . . . . . . . . . . . . . . . . . . . . . . . . . . . . . . 57

Harold F. Heady

Financial Issues Affecting Western Agriculture . . . . . . . . . . . . . . . . . . . . . . 59

Marvin Duncan

Agricultural Exports and the West

Joseph A. Kinney 


\section{Introduction}

Americans have come to take for granted the abundant supplies of foodstuffs produced by our nation's farmers, and their ability to help meet the world's growing demand for tood We have come to expect agriculture's contributions toward easing balance of payments problems, and the employment provided by ever expanding international trade. Somehow we have failed to recognize these dramatic changes in agriculture, perhaps because they occurred in a familiar framework. We must, however, nurture technological advances and encourage the development of even more efficient production, processing and distribution practices.

No longer can we or the citizens of our western states overlook the vital role of agriculture in achieving a sound economy at home and in promoting a stable world society. It is, therefore, most appropriate that the governors of our great western states devote their energies to pursuit of policies that will help advance agricultural production, promote world trade and help assure that our future needs for sustenance will be met.

Richard M. Bressler

Chairman and Chiet Executive Otficer

Burlington Northern Inc.

Seattle, Washington 


\section{The Western Governors}

Ed Herschler, Governor of Wyoming and Chairman of the Western Governors' Conference

Victor Atiyeh, Governor of Oregon and Vice-Chairman of the Western Governors' Conference

Edmund G. Brown, Jr., Governor of California

Robert F. List, Governor of Nevada

Richard D. Lamm, Governor of Colorado

Allen I. Olson, Governor of North Dakota

Ted Schwinden, Governor of Montana

John Spellman, Governor of Washington

John V. Evans, Governor of Idaho

Scott M. Matheson, Governor of Utah

Bruce King, Governor of New Mexico

Bruce E. Babbitt, Governor of Arizona

Jay S. Hammond, Governor of Alaska

George R. Ariyoshi, Governor of Hawaii

Peter T. Coleman, Governor of American Samoa

Paul M. Calvo, Governor of Guam

Pedro P. Tenorio, Governor of the Commonwealth of the Northern Mariana Islands 


\title{
Section One \\ Food in the West Plenary Session
}

\author{
June 3, 1982 \\ Western Governors' Conference \\ Gleneden Beach, Oregon
}

Moderators:

Governor Richard D. Lamm, Colorado

Governor Ted Schwinden, Montana






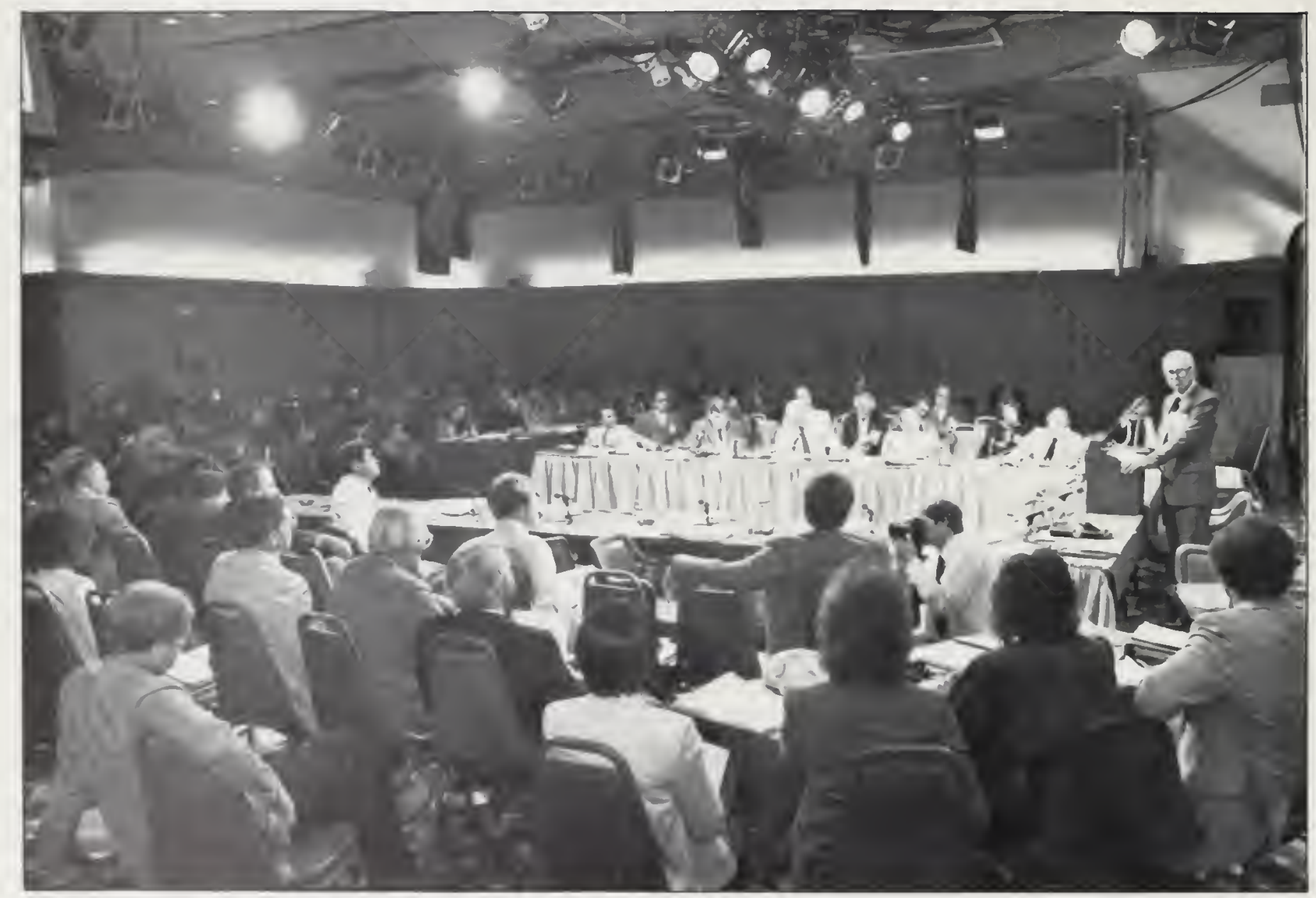

Norman Bortaug, Nobel Laureate, addresses the Western

Governors' Conference 


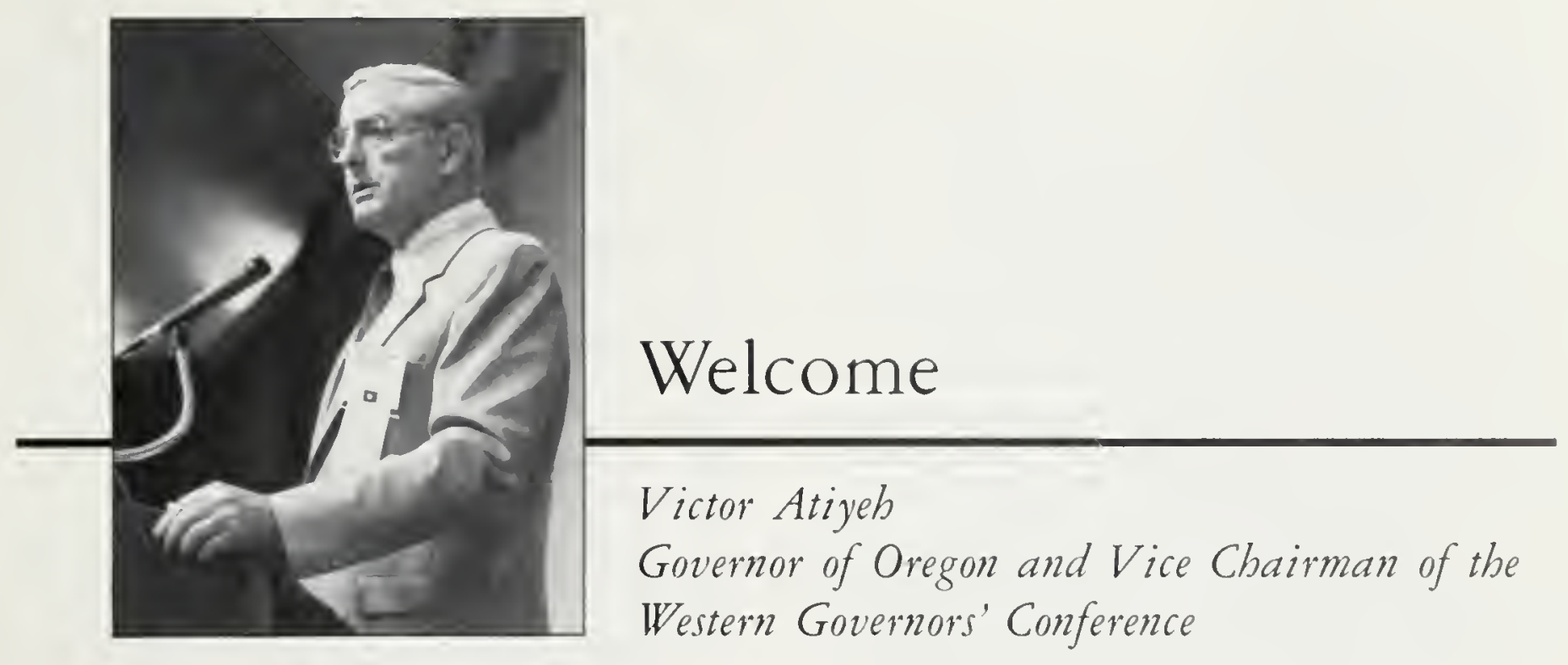

G

Tovernor Herschler, fellow governors and honored guests, I am pleased to welcome you to Oregon.

Our government, our industry and our citizens have generously joined hands - so that we may be as perfect a host as possible while you are here. And, I must tell you that I am very pleased to welcome the distinguished officials and panelists who have assembled here in the beautiful and gracious setting of the Oregon coast to discuss the very serious issues that occupy each of us. We are delighted to see you, and we are looking forward to a productive three days together.

We could not have selected, for many of us, a more timely occasion to learn from each other, exchange information, and work together on common concerns.

And I do mean "work." I have said time and again that one of the things I like about the Western Governors' Conference is the fact that we as governors get together and we do work to articulate strategies that we can put into action and bring home to our citizens of our respective states and territories the things we have learned here.

There is much to concern us here. Forty-five of 50 state legislatures have already met this year. For the vast majority, the news was bad and the meeting was painful.

Only nine of 45 states have been able this year to avoid major budget cuts and increased taxes. The nationwide recession has meant revenue shortfalls and serious budget crises in most states. Thirty legislatures this year have had to face up to budget deficits prohibited by their state constitutions
Oregon is one of them.

I called Oregon's legislature into special session once already in January of this year to balance our budget in the face of a serious revenue shortfall. Yesterday, I again announced a special session for June 14 th because of the continuing lag in our own revenue forecast. We have stretched budgets in Oregon until virtually no slack is left. We are searching for strategies and incentives to help our ailing housing and forest products industries. We are at the same time moving strongly to achieve a more diversified economic base for our timber-dependent economy.

It is a story that may sound all-too familiar to you Services are being cut, state employee work forces are being reduced, and new revenue mechanisms are being explored by many of you as well. Idaho's revenue shortfall, for example, has already precipitated a 4-day work week and severe limitations on in-state as well as out-ot-state travel. And Governor Evans is facing another shortfall forecast even as we meet this morning.

I need cite no more examples of why "Economic Issues in the West" is the central theme of our conference this year.

In fact, this 35th Annual meeting of the Western Governors' Conference is much different from last year's meeting in many respects. Last year, as Governor Herschler's guests in Jackson, we focused on natural resource issues land, water, on- and off-shore energy development, and other matters of concern to the Western states.

But this year, the economy has affected us all. We have been challenged to do more with less in so 
many ways that it might be a good time to remind ourselves of the importance of our region, the ways in which the problems of our region are important to the nation as a whole, and the role of the Western Governors' Conference in examining these matters.

The Western Governors' Conference is one of the oldest, most active regional governmental organizations in the nation. We have operated actively and consistently for 35 years. Through intormation, research, interstate trouble-shooting, education, and federal-state liaison, we have developed a strong regional forum not only for issues among ourselves, but for issues arising from the presence and operations of federal government in our region.

The impact of the federal government on the Western states is enormous. More than any other region, we feel the hand of federal policy, federal practices, and federal mistakes. The rights held by and the decisions made by any region's largest landowner would be matters of grave concern to anyone. For us, the concern is doubled because it seems that everything we try to do as governors in this economy is dependent upon federal cooperation - yet the root of so much of our present difficulty is in federal practices over which we have little control.

In Oregon, we used to have a restraint we put on our prisoners to prevent their escape. It was a large. heavy metal boot we slipped over one leg. It became known, famously, as "the Oregon boot," and it was famous for impeding movement, slowing down the prisoner and encumbering him to the point that every motion he tried to make was rendered awkward, slow, and tedious.

Governors, the current federal budget battle, hundred-plus-billion-dollar federal deficit, and the high interest rates supported by that deficit are the "Oregon boot" that all of us are wearing as we try to turn our economies around. At this 35th Western Governors' Conference, I want you to join me in trying to do something about it.

We have taken and supported regional action before. We have initiated the Western Interstate Energy Board, the Western States Water Council, the Western Interstate Commission on Higher Education, and many others

And, I might mention to you, as recently as two days ago, the Western Interstate Commission on Higher Education had a committee looking at high tech, graduate work in science, and how we - collectively as governors in the Western region - can meet those needs through our institutions of higher education. It was a very successful meeting.
Through our efforts, we have supported many specialized regional organizations created through compacts, and we have individually and jointly participated in the efforts of many affiliated organizations attempting to solve problems on a regional basis.

We must continue to be even more strongly problem-oriented, and we must redouble our efforts at problem-solving

I do not need to remind any of you that the era of revenue sharing - of increasing infusions of federal dollars - is over. We will be taking on more responsibilities of the federal sector, but we will have to do it with drastically reduced financial resources.

As we have in the past on water rights and allocation, we must make our voice and policy choices heard ever more strongly as critical decisions are made in Washington.

We Western governors have a natural forum, right here, to affect federal policy. The nation is actively seeking economic expansion as a way out of this recession, and the West has been vital to the economic expansion of our nation since its earliest days.

We are the region that contains the natural resource base of America that supports the economic base of America. That is why we are in a special position to make certain that our voice is heard

At this conference, we are particularly enriched by the presence of a territorial governor from the Pacific. That is because we are, as a region, increasingly looking to the Pacific Rim countries as the most dynamic growth area in the world economy. Oregon alone has sent numerous trade missions to the Pacific Rim during my administration, and the trade we have won has helped keep many Oregon businesses alive - while preserving countless jobs, and I know each of you has made trips as well. As a matter of fact, Governor Spellman got back last night.

We regret not being able to accommodate the schedules of the Western provincial governors of Canada, but we are fortunate to be able to hear from Mr. Robinson, our distınguished U.S. Ambassador to Canada, at luncheon today

Under Governor Herschler's guidance as program chair, we have assembled a schedule for you filled with both variety and challenge. We will be able, in these sessions, to step aside momentarily from daily state administration to share our perspective on issues and alternatives that cross state lines and affect us on a regional and Western basis. I believe that we can gain an invaluable view of common challenges in tough economic tımes. 
I look forward to sharing with you Oregon's perspective on these challenges over the next few days. We, as well, have been challenged to do more with less, and we began that process in the early days of my administration as governor. We have been prudent. We began cutting budgets and implementing service reforms that have enabled us to blunt some of the impact of the recession and reductions in federal tunds. And we concentrated very early on diversitied economic development for our timber-based economy

But we have not done enough. Like most of you, we too have been hit by the downturn - and hit hard. High interest rates have devastated our housing market - despite one of the largest and most successful veteran's home loan programs in the nation. The housing slump has devastated our forest industry - the pillar of our economy. Only five states in the nation have a greater jobless rate than Oregon. At least one of the five, Washington state, 12.9 percent is represented here today. Oregon is at 11.4 percent.

We, also, are wearing the "Oregon boot," but we are looking at policy initiatives for our forest products industry base that we can bring to Congress with your help.

I am announcing today my endorsement of a change in the way timber harvest decisions are made nationally. My goal, and, I believe, your goal is to achieve a stable supply of timber at an affordable price, which will allow Westerners to compete successfully with other regions and foreign markets. Currently, these decisions are made based on very volatile housing start assumptions that rise and fall at the mercy of - among other things - interest rates. I believe that the U.S. torest products industry would be better served by a broader base of assumptions reflecting not only housing starts but increased markets - both domestic and international - for finished products.

The Western Governors' Conference is a forum for this policy goal. By approaching Congress and the Administration as one region and one group of governors, we can speak with one voice and be heard. Our initiative can help stabilize and conform the actions taken by the Bureau of Land Management and the U.S. Forest Service.

I mentioned this announcement this morning, actually, so we can begin uniting on not only the issues that I address, but uniting on the issues that you will bring to us.

The ultimate message to you this morning is not only that Oregon welcomes you. It is that Oregon is listenıng to you The people of our state are following our deliberations.

All of us are groping for answers. We will not have answers in three days or in three months. But we can emerge from this conference with a problem-solving agenda, a series of joint initiatives, and an acute awareness of the tasks we tace and the steps we must take

To find solutions, we must explore ideas. Our nation was founded on ideas. The translation of our ideas into action is the process through which our nation retains its great spirit and magnificent vitality.

I am an optimist. It is often said that an optimist proclaims that we live in the best of all possible worlds, while the pessimist fears that this is all true

I suppose, at the very least, that optimism means making the best of it when you are getting the worst of it.

I conclude this morning with optimism, because it is that generous spirit that has brought us together today. The generosity of private industry has made possible this 35th Western Governors' Conference to come together as well as we have. It includes the generosity of many companies who are suftering with us through this recession and companies who are as interested in turning our economy around as you and I are. They are optimistic about our ability to do so

So, it is time for us to get on with the business about us in the beautiful surroundings in which we tind ourselves.

What we learn here can measure our solutions as well.

I would like to, again, greet the governors and our honored guests, and again say to you, welcome to Oregon.

I thank you all very much for being here and sharing your wisdom with me. At this point, I think it is time we return to your chairman, Governor Herschler. who will proceed with the program that we are all eagerly looking forward to. 


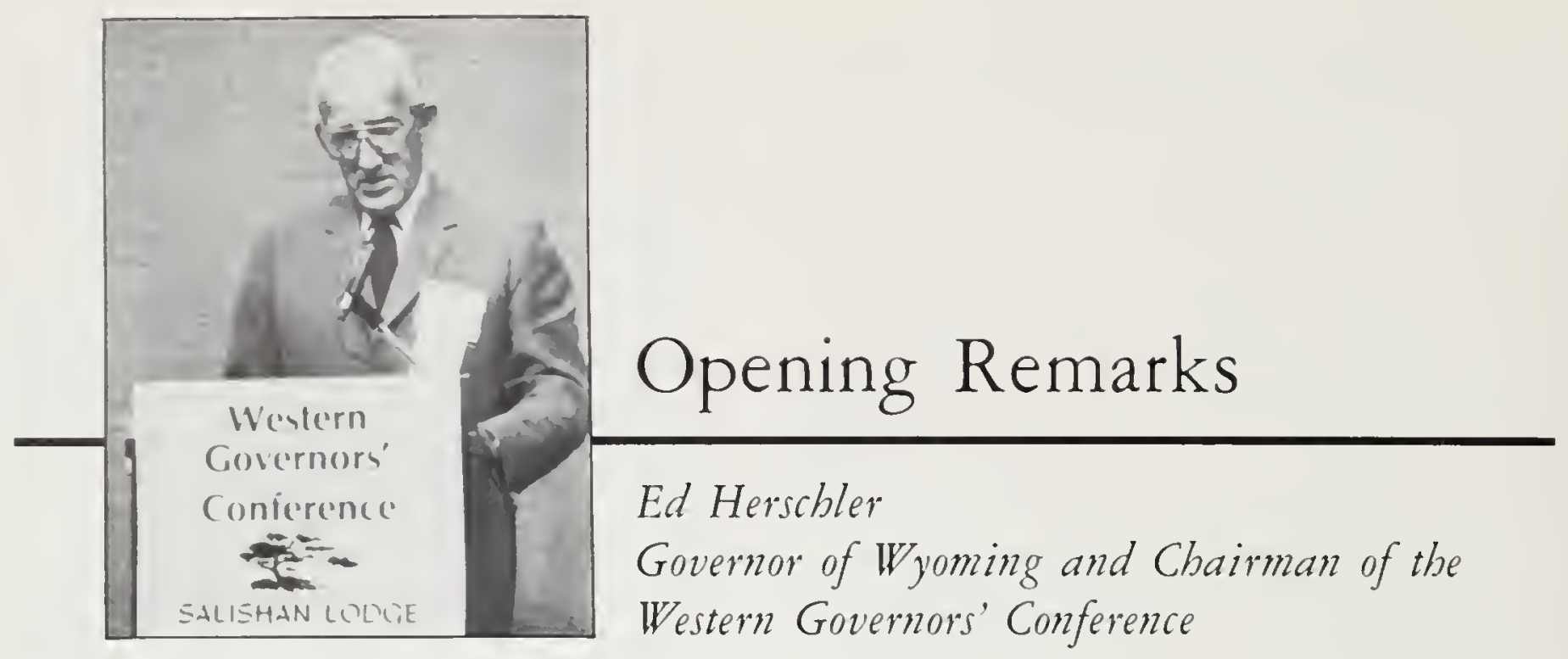

$\mathrm{M}$

y fellow governors, distinguished conference participants and guests, let me add my welcome to our annual meeting here at Salishan.

Governor Atiyeh, we have already felt the warm hospitality that you, Dolores (Mrs. Atiyeh), your staff, this marvelous facility, and the private sector contributors have all collaborated to provide.

Governor, we are all trying to do our job by coming to your beautiful state to boost your economy. You certainly had uncanny foresight last summer to know that some $350-400$ visitors to Oregon at this time would provide a much needed lift - we're glad you did - and we hope we do!

Less than a year ago, most press accounts of our region painted a prosperous picture of a robust economy. Energy development projects were booming. new capital and new people were streaming into our region in search of the "good life." And, as governors, when we met in Jackson, Wyoming, in September 1981, our concerns were focused on how, as chiet executives in the Western states, we were going to manage those promising developments in an orderly way. We wanted to contribute our respective natural resources to meet growing national demands, and we have consistently sought to do so in ways compatible with our unique Western values and lifestyles. As a result, this past year, we dedicated ourselves to adopting policies and pursuing work programs aimed at

1 Strengthening state roles and capacities to participate as a full partner with the federal government in natural resource policy management, and,
2. Broadening our respective state economic bases so as to provide more secure financial futures.

As part of our meetings here we will be reviewing the work of the past year, including the status of:

- The 26 major land, water, and energy-related policies we have advanced to the interior department,

- The federal gas and oil royalties underpayments to the states and accounting problems we are attempting to correct,

- The regional low-level radioactive waste disposal compacts we are pursuing within our respective states

- The western state correctional and prison management improvements we have recommended in our regional study; and

- The International Trade promotion activities we have sponsored in an effort to substantially increase Western state exports in this decade

All of these work programs will be closely examined through our committee meetings and at our closing business session when New Work program priorities for our conference will be proposed. All of you governors should have received a bound document entitled Western Governors' Conference Workplan Report upon which our program assessment and development activities will be based

For our major plenary sessions today and tomorrow, however, we have decided to look at some of our special Western state economic sectors so critical to our regional well being. As we gather here, we are once again powerfully and painfully reminded how vulnerable virtually all of our Western states are to 
external domestic and international events. When interest rates remain unreasonably high over a prolonged period, new housing starts drop seriously, and the timber and lumber industries are shut down

When there is a glut in the world oil supply, projects in Western states take years to get underway, and some of them come to a sudden halt. Just ask Governor Lamm about oil shale in Colorado these days.

Thus, our plenary sessions here are devoted to examining selected of our most important, yet, dependent economic sectors in the West. In chronological order, we will analyze and discuss:

1. Our agricultural economy - with an emphasis on where we are and where we should be heading over the rest of this decade to improve our agricultural output, efficiency and economy;

2. The national economy and budget situation, including a full examination of the causes and consequences of current policies and alternative actions, particularly as they aftect states;

3. The housing economy, looking particularly to possible policies which would serve to even out the extreme highs and lows of this economic sector; and,

4. Our marine and coastal resources, with a view on their strategic and economic importance to the nation and to the West

In addition to these plenary sessions, and our work program and policy setting meetings, we look forward to hearing from the U.S. Ambassador to Canada, the Honorable Paul $\mathrm{H}$. Robinson Jr. at lunch today, and to discussing with White House ofticials on Saturday where things stand on the President's "New Federalism" proposals.

We have a full agenda ahead and I think it's best that we move directly into it. But tirst, as Governor Atiyeh mentioned, I would personally like to welcome Governor Pedro Tenorio, of the Commonwealth at the Northern Mariana Islands, to his first meeting of the Western Governors' Conference. Second, I want to request, in conformance with the rules, that any governor wishing to submit a resolution to the conference please do so by 5:30 p.m. today. Submit them to the Western Governors' Conference staft or to the Resolutions Committee Chairman, Governor Spellman of Washington.

It is now my pleasure to introduce Governor Lamm of Colorado and Governor Schwinden of Montana who will moderate our session on "Food in the West."

Governor Lamm... 


\section{Panel Moderator:}

Richard D. Lamm

\section{Governor of Colorado}

Governor Herschler, continuing on the same theme that you are talking about in your welcome, and Governor Atiyeh, thank you for your warm welcome.

The history of the West is a history of boom and bust. We're booming one minute and we're busted the next. We saw this in Colorado where Exxon promised us a tiger in our tank and we ended up with a white elephant in our backyard. This has really been the whole history of the West. We have had phenomenal economic development one minute, only to be left with a hole in the ground the next.

The one exception to this, the one sustaining economy in the West, has been agriculture. It has been the glue that has held our economies together. When silver busted, when they signed the repeal of the Sherman Silver Purchase Act, when a depression hit, when economic cycles, in fact, hit the West so much harder than other places, when those happened, in fact, it has always been the yearly sustaining yield of agriculture that has bailed us out.

Unlike the copper in Utah or in Montana, or oil shale in Colorado, agriculture comes up every year. It is a yearly harvest as opposed to a one-tıme harvest, and I think that is why it is very appropriate that the program, in lact, deals with food

Dotty and I spent some time in India about 15 years ago, and there is nothing that gets a person's attention like stepping over starving and dying people for lack of tood.

It is an appropriate topic, and we have some excellent panelists to deal with it. A Nobel Peace Prize



recipient, a leading agri-business and transportation executive and the president of a leading research organization, who we will start with.

Dr. Emery Castle is president of Resources for the Future. At Resources for the Future he recently announced a new project on lood and agriculture. He was previously dean of the graduate school of Oregon State University and an agricultural economist. We are honored to have him, Dr. Castle... 


\title{
Panelist:
}

\section{Emery N. Castle}

\author{
President of Resources for the Future, Inc. \\ Washington D.C.
}

$\mathrm{T}$ hank you very much, Governor. It is certainly a pleasure to be in Oregon, and when I get an invitation to come back, I don't usually argue very much, and certainly an opportunity to address the Western Governors' Conference is very much of an honor. I am saddened, of course, to come back to Oregon and see the depressed economy that exists here, and I feel for the people that I worked with for 21 years, and I feel for the institutions that I was associated with for so long. U.S. agricultural exports have approximately doubled since 1970. This has been caused by population growth abroad, mismanagement of agriculture in the Soviet Union and some of the centrally planned economies, and, most importantly, because of income growth in the developing societies. Both political parties in the United States favor even greater expansion of exports. This would please those who are in the business of producing and selling foodstuffs, and the earned foreign exchange would be welcome as well.

Yet, I do not believe that the next two decades will see a simple extension of the trends that began in the 1970s. Our exports will continue to increase, but they will be limited, shaped and influenced by a number of tactors now coming to the fore.

Global international trade in agricultural products has been growing at approximately twice the rate of increase in agricultural production. While this rate of growth obviously will not continue indefinitely, international trade will become increasingly important. Many of the developing countries will import more and some will export more, and greater exports are probable for both North America and Western Europe as well.

The enormous increase in demand for agricultural products during the 1970s was generated in large part by people with improved incomes who wish to consume more animal products. Add to this the fact that many of the resources of Africa, where hunger will be the most severe for the remainder of the century, are best utilized by livestock. Now the full significance of these combined trends has not been fully appreciated But at least it is clear that great social returns will result from improvements in livestock efficiency. This is not to say, of course, that improvement in plant efficiency will not be important also in the future. It obviously will be. But it is to call attention to the increased importance of livestock over the face of the globe and to indicate anything that can be done to improve livestock production, livestock efficiency, will indeed generate great social returns. Projections made by the International Food Policy Research Institute and others indicate that the United States must contribute handsomely indeed if the global shortfall in food production is not to be very large by the end of the century.

What then is the ability of the United States to respond to this growing world demand for food? The answer depends importantly on public policy. Currently, for example, the strength of the dollar against other currencies is discouraging exports. The price of U.S. agricultural products has been falling relative to other goods and services within the economy, the domestic economy. But those products have been increasing in cost as measured against other currencies. Research and educational policies will also affect the productivity of our agriculture, as will price supports and conservation policies. So, I am able to say this morning that politicians do make a difference 
in world agriculture.

Costs lie at or near the heart of every public policy decision - a truism of political life that probably was never more acutely appreciated Accordingly, I want to discuss some of the major determinants of agricultural costs with particular reference to land, water, and energy. I will also offer a few remarks about agriculture and the environment, and about the close relationship of research and education to the availability of natural resources.

\section{"Costs lie at or near the heart of every public policy decision - a truism of political life that probably was never more acutely appreciated."}

First, land.

The availability of land to produce food and fiber depends on how much land is converted from agricultural to urban and other purposes, and on how much top soil is lost to erosion. I take up these issues in turn.

In my judgment, the debate over the conversion of agricultural land has focused on the wrong question. Trying to answer the question. "Are we in danger of running out of prime agricultural land because of the conversion of agricultural land to urban uses?" , is not likely to yield information helpful to public policy. A far more useful question is, "Are food production costs likely to rise in any significant way because of land conversion?" This question is answerable and can serve as a guide to public policy. Even under quite liberal assumptions about the rate of conversion, the cumulative loss of cropland because of conversion is unlikely to exceed 5 percent of the total until after the year 2000. Thus, even if policies designed to slow the rate of conversion had been effective - which they have not been on a national basis - and widely adopted, they would not make a large contribution to future food production. This is not to argue, of course, that the acreage suitable for cropping is not limited, it is, or that there is a great amount of unused land waiting to be developed, there is not. But it is to say, that if we placed the issue in perspective, we see that the problem is a relatively small one that must be kept in perspective, if judged on the basis of food and fiber production.

However, cropland conversion is a most important problem to many local areas because of environmental considerations, the loss of open space, or because of its impact on the nature of a community or an area But it is not wise public policy to try to solve these problems under the guise of a food shortage or rising world food costs. If real agricultural product prices rise, it will not be because of the conversion of cropland to urban users.

Soil erosion has been the source for a great deal of recent concern. Much of it useful because it has directed attention to some most disturbing trends. Mainly farmers feel pressured to bring more erodable land into production and the export of grains and soybeans has resulted in practices that are exploitative in nature. Even so, the useful question, "Will soil erosion likely increase the real cost of agricultural production in the future?", is not easily answered, even though it is possible to offer some generalizations.

First, the problem, whether it is major or minor, varies greatly in severity among regions. Almost all of the worst erosion by water occurs on 10 percent of the land, yet our policy has generally been formulated and executed on the implicit assumption that soil erosion is equally serious in all farming regions

Second, no one really knows the long-run impact on productivity from continued erosion in excess of 5 tons per acre, which is the official "permissible" soil loss figure. This is so because soils vary greatly with respect to the effect of soil loss on productivity, because many factors, in addition to erosion, affect productivity, and because future technology is unknown. The problem deserves careful and intensive investigation, but I do not believe future costs are likely to rise sharply because of the current rates of erosion. But that is indeed a judgment that subsequent research and experience might well show to be faulty. Furthermore, significant off-farm costs do result from soil erosion. The siltation of dams, for example, and this is an important social problem quite apart from what may or may not be happening to agricultural productivity.

I turn now to water and agriculture.

I begin by quoting from a recent RFF study by Kenneth Frederick, entitled Water for Western Agriculture. "Irrigation has been an important factor in the impressive performance of U.S. agriculture in recent decades. Irrigated acreage tripled from 1940 to 1977 and doubled from 1950 to 1977 , periods of great increases in agricultural productivity but virtually no change in total cropland use. Average yields are greater on irrigated than on non-irrigated farms, and within the arid and semiarid areas technological 
change has been higher on irrigated farms Thus, while irrigated land currently accounts for only one-seventh of the nation's cropland, it accounts for more than one-fourth of the value of the nation's crops." (p. 1)

Now this quotation, I believe, is an accurate summary of the past and current contribution of irrigation to agricultural production, but these past trends will not continue into the future and the future contribution of irrigation to increased production will be less than it was in the past. In the West, the lowest cost water already has been developed, ground water levels are declining, and the value of water in non-agricultural uses is increasing. In the East irrigated acreage will continue to grow but its contribution to aggregate production will be less than it has been in the West in the recent past. In some parts of the Great Plains and elsewhere in the West, declining ground water levels have reduced output. In other areas salinity has become a limiting factor in production.

Some people have added up these trends and predict a crisis. I am not one of them. In fact, I find little basis for alarmist statements that we are facing a massive water shortage in the 1980s, nor does there seem to be any basis for the notion that aggregate agricultural output will suffer greatly as a result of the loss of agricultural water to non-farm uses. About 90 percent of the consumptive use of water in irrigated areas is in agriculture. In most such areas water is used quite inefficiently in a physical sense because of its low economic cost. Should water become less abundant or higher in price, its agricultural use would become more efficient, or it already has become more efficient in some areas, and it is unlikely that aggregate agricultural output would suffer significantly. I should make clear, however, that this assumes our water institutions will be sufficiently responsive to transfer water to its highest and best use and that its user cost will reflect not only the cost of making it available but its productivity as well.

Now for a few comments on energy.

Most energy analysts predict that the real costs of energy will increase during the 1980s and 1990s. If this turns out to be correct, I believe the impact will be greater on food marketing and distribution than it will on on-farm production. Higher energy costs probably will not do much harm to the competitive position of the United States in the production of lood because other food exporting areas are likely to be hit by the same cost with similar effects.

Agriculture and the Environment. Pierre Crosson and Sterling Brubaker of our staft have discussed this subject in a most thorough and systematic way in a forthcoming book to be entitled, Resource and Environmental Impacts of Trends in U.S. Agriculture. They examine very carefully the evidence regarding environmental threats posed by insecticides, herbicides, fertilizers, and erosion. They conclude, and I agree, that with the exception of erosion, most of these threats can be met without increasing production costs significantly it we are prudent managers. Now for some final comments.

I have identitied some disturbing trends. We do not have a large unused cropland base, soil erosion is severe in some areas, irrigation will not increase in the future to the extent that it has in the past, energy may become more expensive, and many agricultural inputs need to be managed carefully if undesirable environmental impacts are to be avoided.

Still, should the costs of producing U.S. agricultural products that enter into world commerce rise, more than such costs in other exporting regions for the remainder of this century, I do not believe it will be because of greater natural resource scarcity in this country

The major determinants of costs will not be the limits of our natural resources, but rather the limits on our imagination and our creativity. On what production innovations, if any, are forthcoming, and the way they are managed and applied. Here the investment in research and education in both the public and the private sector will be most significant. I now comment briefly on just one aspect of managerial efficiency made possible by technology that is often overlooked in discussions of sources of agricultural productivity growth.

$$
\begin{aligned}
& \text { "The major determinants of costs will } \\
& \text { not be the limits of our natural } \\
& \text { resources, but rather the limits on our } \\
& \text { imagination and our creativity." }
\end{aligned}
$$

I refer to the enormous strides that have been made in the collection and transmission of information, advances that have not yet been fully implemented in agricultural production. One reason we do not have giant corporatıons in agriculture, generally, is that biological organisms - plants and animals - require many small decisions if they are to produce economically. And these decisions have not been standardized to the extent necessary to make mass production 
possible. "Compunications," the use of computers combined with the techniques for collecting, organizing, and transmitting information, holds the potential for greatly improving managerial efficiency. Other advances will be needed, and some doubtless will occur. But this will be one way of increasing yields per acre, per animal unit, and per unit of managerial input. I am not predicting that, if this were adopted, this would necessarily result in huge farms. That is not the point. The point is that I think it is the source of technology that has not yet been fully exploited.

Now, in summary I believe agricultural exports trom the United States can continue to grow, and that the welfare both of the United States and of people everywhere will be improved if our exports do grow. As I have suggested, public policies will influence the outcome in several important ways. And I reiterate just four examples

1. The strength of the dollar against other currencies discourages agricultural exports.

2. Agricultural exports depend on efficient agriculture, and efticiency depends on both public and private investment in agricultural research.

3. Exports based on exploitative farming practices are not sustainable. We very much need to pinpoint erosion problems, determine their severity, and take the necessary public policy steps to correct them.

4. The institutions governing the development and allocation of water between agriculture and other uses are not working as well as they should We must better understand these institutions so that public policies can be adopted that will improve their performance.
Governor Atlyeh, I say that based on not only readIng books and studying research reports, but ten years of experience with Oregon's Water Policy Resources Board.

U.S. agriculture is marvelously productive, but it will not stay that way if we ignore the current and emerging forces that will shape its future. The most important crop of the next two decades may well be the design and nurture of effective public policies and institutions.

Thank you. 


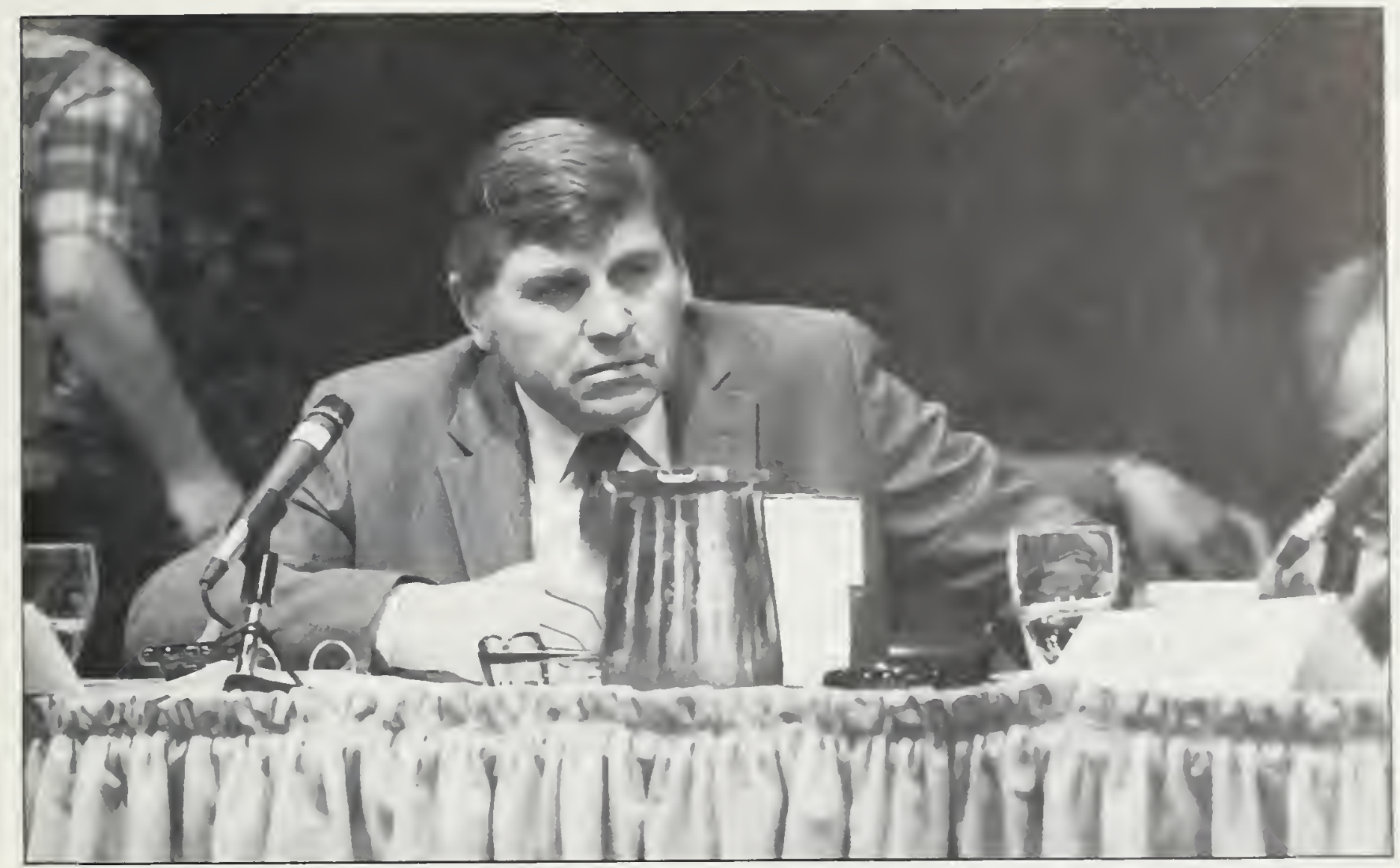

Bruce King. New Mexico, keys on speaker's theme. 


\section{Panel Moderator:}

\section{Ted Schwinden}

\section{Governor of Montana}

I'd like to introduce the next two panelists that we're fortunate to have this morning. Governor Herschler. It is appropriate that a farmer gets to introduce a couple of folks who are going to talk about food in the West, because the issue certainly goes beyond the West. It goes to the American productive machinery that puts so much food on the tables of Americans and the rest of the world.

Dr. Castle talked about the potential impacts of a variety of factors on food and food costs. The Department of Agriculture has recently projected that farm income levels this year will drop to approximately 1935 levels. In terms of public policy and in terms of who's going to be doing the farming, this is going to have some impact on cost down the road.

I think it's important that we examine in our discussion this morning the productive system - whether it's going to change radically as a result of the erratic changes in the status of farm prices and in terms of the change that's occurring, sometimes subtley and sometimes fairly dramatically, in terms of the ownership of the American farm production machine, if we can call it that.

Certainly one of the areas that will impact, if not ownership, at least the cost of lood production and the future role that the West will have in supplying lood, is represented by our next panel participant this morning, and that's Mr. Richard Bressler.

To simply introduce Dick Bressler as the Chairman of the Board and the Chief Executive Officer of Burlington Northern Incorporated, a relatively new holding group with interest in the area of transportation, real estate, and forest products interests, is a misleading introduction because those areas of interest, of course, are tied very closely to the present and future of the West, especially in terms of cost and the adequacy and the availablility of transportation. The utilization of resources, particularly of timber and energy. are a part of the holding company.

Dick is a member of the President's Export Council and serves on its agricultural subcommittee. He has had a lot of publicity lately, which reflects the tact that he is one of this nation's leading transportation and agribusiness executives. Certainly in terms of states like Governor Olson's and my own and indeed all of the West, the role that particularly transportation plays - just as the railroads in the 19th century, in effect, dictated the settlement patterns of the West to a significant degree - in the ability of the West to compete in terms of food production. The future is going to depend upon the availability and the viability of that transportation system.

Mr. Dick Bressler... 


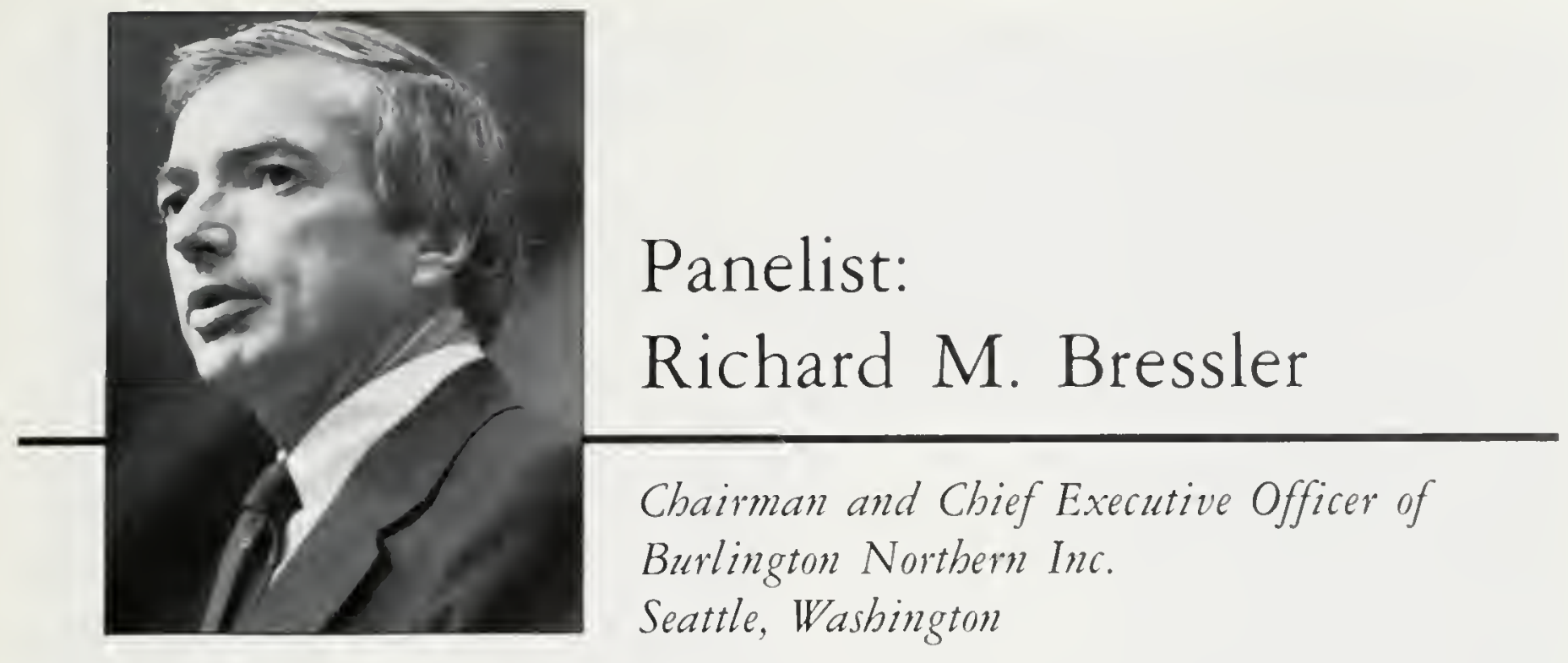

$\mathrm{T}$ hank you, Governor Schwinden.

I was enjoying the entertainment last night that Governor Atiyeh so nicely arranged for all of us. I was listening to our astronauts describe their trip, and I enjoyed that description until Gordo and Jack started to describe the Columbia as a transportation system with a large excess payload. My God - more competition. Vic, you've always been very subtle at reminding $\mathrm{BN}$ to keep on its toes out here and I expect more of the same

I've been associated in one way or another with agriculture in the West ever since I grew up in a small town in Nebraska. I can remember well searching the sky to make sure that there were clouds around, to see if it was going to rain, or if it was going to rain too much, or heaven forbid, if it might hail. Agricultural entities have always had perilous times, so it is with some nostalgia and a great sense of honor that I currently serve with Governor Charles Thone (Nebraska) on his agricultural committee of the President's Export Council.

That's a partıcularly frustrating job, frustrating because of the poor health of our agricultural establishment today. Those frustrations carry over into my full-time job as Chairman of Burlington Northern, which is the country's largest grain hauler and heavily dependent upon the success of agriculture, particularly in the upper Midwest and here in the Northwest

When you look at the ills of agriculture today, you see how little any of us who are heavily dependent on and involved in agriculture can do to make it right. I'm citing things like high interest rates, the fact that

we have a worldwide recession, that we continue as a government policy to use food as an instrument of foreign policy, which I think is very detrimental to markets. I'm sure many of the governors here who have visited the Pacific Rim countries know that when we cut off tood to Russia it attracted the attention of the Japanese and the Taiwanese as well. They don't like the possibility of disruptions of markets

So, those are elements that are really outside the ability of any one of us to control. I think all we can do is to speak up at appropriate forums, such as this, to add our voices to ensure that agriculture and agricultural exports are healthy in this country

What can a company like Burlington Northern do then, given the fact that we can't influence some of those external environments? What can we do to help ourselves and help agriculture at the same time?

I could cite things like what we're doing here in Oregon, working with the State of Oregon to reopen the long dormant grain terminal at Astoria. It looks like the prospects for that terminal to be reopened as an export terminal are good If that should happen, we see the possibility of an export potential of 120 million bushels a year through that terminal by the mid-80's, and that would just be great. We've pledged that we will do what is necessary to rehabilitate our railroad line to Astoria to help make that happen.

I could also cite cases where we have given some of our tinancial resources to institutions like the University of Nebraska to study the more efficient use of water from the Ogallala Aquiter for irrigation purposes. We see that as a useful thing 
But I think most importantly, our objective is to maintain the lowest possible transportation cost for the grains grown in the upper Midwest and here in the Northwest, to move those to export in the most efficient manner possible. Today, we are doing that through a device that we call a unit train. We are now engaged in moving large quantities of grain via these 52-car trains, 100-ton cars loaded all at one origin and moving as a unit to an export terminal.

In so doing, we have maintained, and in fact, have cut the cost of moving a bushel of grain, let's say from central Montana. If you use 1960 as a base, and in terms of 1960 dollars, we have cut the cost of moving that bushel of wheat by about half today. That hasn't done the farmer all that much good with worldwide depressed grain markets, but it's our contention that this will be the efficient way to move grain, and we believe that it is beneficial to farmers.

"If you use 1960 as a base, and in
terms of 1960 dollars, we have cut the
cost in moving that bushel of wheat by
about half today."

That is not to say that in the process of doing so, there is no trauma involved. Our friends here, $\mathrm{Al}$ Olson and Ted Schwinden, know that when we boost the movement of grain via the main line and have to abandon branch lines, that always causes some trauma. We're well aware of that. But we are still committed to our objective and that is to be the lowest-cost and most productive mover of grain to the Northwest ports. And that's our commitment.

Let me conclude by saying that I'm also an optimist. I think, like governors these days, businessmen have to be optimists. I guess otherwise you wouldn't get out of bed in the morning. But I see that U.S. agriculture, and particularly markets for American grain, will revive because I believe we are the low-cost producers and we will continue to be. And, we'll see great movements of grain again. Hopefully, it will come sooner rather than later, so that we don't have many more months of the kind of trauma that farmers and some of the rest of us are going through today.

Thank you<smiles>CC(C)(C)C</smiles> 




Gov John Spellman, Washington, listens to corporate constituent. 


\section{Panel Moderator:}

\section{Ted Schwinden}



\section{Governor of Montana}

Our last panelist today is one of the foremost scientists in the world, Dr. Norman Borlaug. His efforts in the green revolution and the transtormation of the agricultural landscape to produce more food for people who need it to survive earned him, of course, the Nobel Peace Prize, some 12 years ago in 1970 True to his character and his commitment to an industry that I happen to belong to as a farmer, Dr. Borlaug was working in a wheat field at the time the award came, and if I know Dr. Borlaug, I suspect he completed whatever he did before he responded to the media request because that is the only way that you can operate a farm. And that includes the breeding of wheat.

For almost four decades, Dr. Borlaug has shunned the comfort of academia in the U.S. for the life of a wheat breeder and a helper to American agriculture and hungry people around the world, and in Mexico. As he strives to improve the productivity of a grain, he also is working, of course, to improve the quality of life of people all around the world.

It is more than a privilege, if is a genuine honor to present to you this morning Dr. Norman Borlaug... 


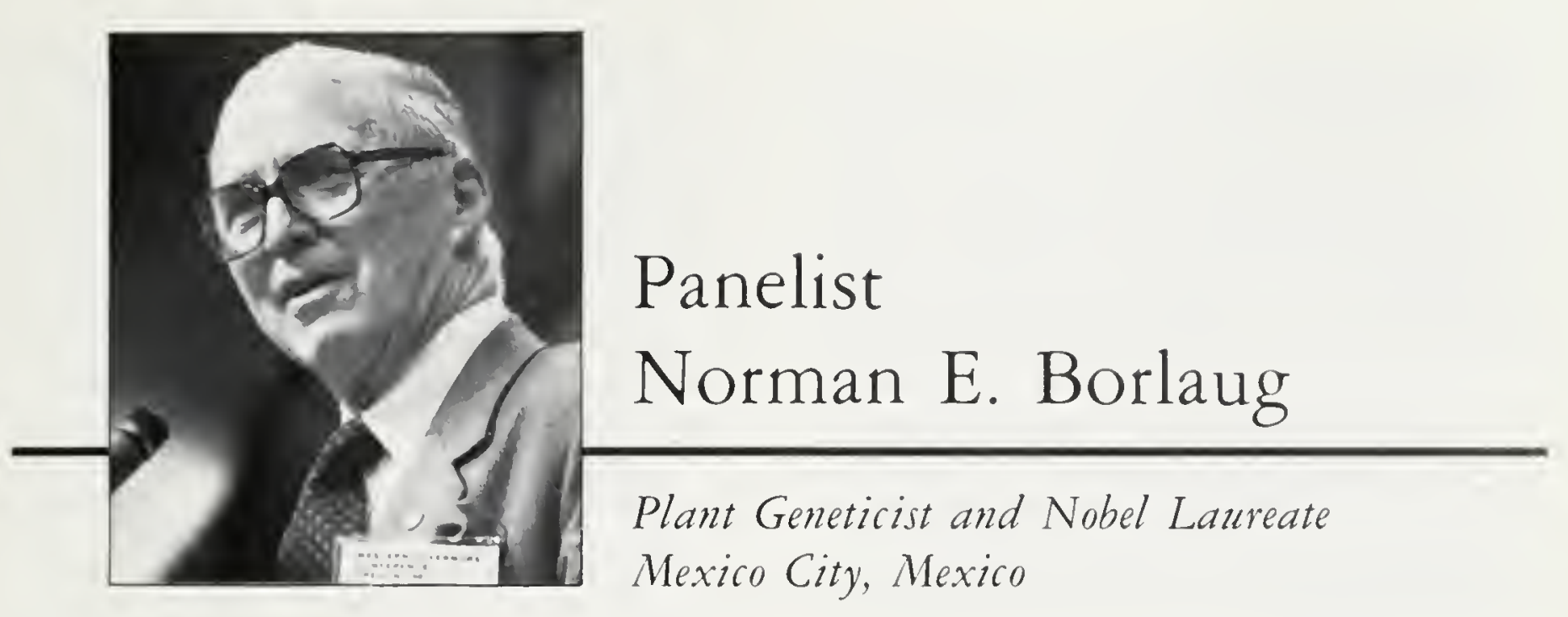

G overnor Schwinden, honorable governors of Western states, distinguished guests, ladies and gentlemen. It is a privilege and honor for me to be here. Seldom do I get an opportunity to participate in this kind of conference, but I have had many opportunities during the last 30 years to participate with political leaders as they relate to their own national and state agricultural problems.

In order to give you a little feel of what makes me tick, I grew up on a very small farm. I had a broad, general farm background. I studied forestry and was interested in the broader use of land. I spent two assignments in Middlefork on a forest that has long since disappeared, the Idaho National. There I learned to know myself. I also got a feel, subsequently, for some of the big problems in the world After I was released from War Manpower and after a brief stay in the chemical industry, which I joined shortly before Pearl Harbor, I took an assignment, the firstborn technical assistance program, at the invitation of the Government of Mexico in a program financed and coordinated by the Rockefeller Foundation. In one way or another, I have been associated with that program and its successors in many different parts of the world for 38 years.

So, I was impressed very greatly last night by Dr Fullerton's and Dr. Hutchinson's descriptions of what the world looks like from space, especially by the remark that Colonel Fullerton made that when they flew over the U.S.A. they could see many of the modifications that had been made here through roads and large cities and what not, but when they flew over India, they saw no real evidence of its 650 million people.
I would like to add that you could not see from above, either, the vast misery and hunger of that nation and many other nations. I will try to weave this into the story that I am going to try to paint for you I think it is important for you governors, as well as for all of our political leaders and agricultural leaders, to understand the problems, strite and struggle of the developing nations, not only to anticipate the growing demands for food, but also how this fits into world political stability or instability

Now, let me start out by saying that you know in our very atfluent, privileged U.S.A., a lot of our people have forgotten where food comes from.

Again, our friends Fullerton and Hutchinson, mentioned that you see these vast expanses of water and ocean and yet, tonnage wise, all of that vast area only produces 2 percent of the total tonnage of our annual food supply. So, 98 percent comes from the land, and only a trace - at this time - of our food and feed comes from industrial fermentation done either by bacteria or yeast. There are those who are very optimistic that this will grow rapidly in the future. I hope it does, but I am not very optimistic that this development will take place very tast.

For those governors who have vast forest areas in the West, I am also of the belief that within the next several decades we will use our forests much more for industrial raw materials that we know about today, but which, costwise, are unprofitable to employ.

What are the kinds of foods? It is a very complex world system. There are different preferences, different places, and also the kinds that are consumed are in a large part affected by income, availability of food in broad categories, though the cereal grains are by 
far the most important - wheat, rice, corn, sorghums, millets, oats, barley, and so on. They are grown on approximately half of the cultivated land area of the world They have the great advantage that our friend here from Burlington Northern can ship them hither and yon more cheaply than most other kinds of food. because they are low in moisture and they can be stored much more easily than perishables. And this lends to developing our vast quantity of international trade.

In addition to these are grains, legumes, pulses, sugars, oil seeds, vegetables, fruits. And then we come to the animal products, all kinds, meats, cheese, milk, eggs. And finally to those things that we call beverages, tea, coffee, Coca-Cola.

It is a vast array. And all of them are important. Some are more important in one part of the world than in others. Much of our feed grain, for example, is converted to meat, milk and eggs. This is a luxury that cannot be afforded in many of the developing nations, where more of their food is consumed directly from grain.

\section{"Based on the best evidence, it's only been 12,000 years since agriculture was discovered - a recent development."}

What is the amount of food that is needed? Without correcting for grain in 1975 when the world achieved a population of 4 billion people, the total production was 3.3 billion metric tons - quite a pile.

Now let's take a look at what this growth in demand has been and what it is likely to be for the next several decades.

Before we do that, we have to set the stage a bit. The planet Earth is about 5 billion years old and the photosynthesis that we all depend on, either directly or indirectly, for our food, based on the best evidence available, is also very old. The blue-green algae seems to have been in existence 3.2 billion years ago - not the day before yesterday

Man was a "Johnny-come-lately" species to this planet Earth. So far as we know now, only 3 to 5 million years ago, and by the time he arrived, probably 98-99 percent of all of the species that had ever existed on this earth had become extinct.

So when we talk about endangered species, let us be careful. I think we have got some very great elitists with a great deal of political lobbying power that are disturbing the total picture as to what is going to happen to the planet Earth and its life system.

Now, it is important to understand something about growth in human numbers in order to see what we are likely to be confronted with in the future. Man seemed to wander around most of his existence on earth as a hunter and collector of wild plants and a hunter of wild animals and of fish. Based on the best evidence, it's only been 12,000 years since agriculture was discovered - a recent development. When we stop to think about this tremendous development in that short period of time, I think we should all take a great deal of pleasure in this accomplishment.

At the time of the discovery of agriculture, there were about 15 million people on Earth. From then until the time of the Christian era, population doubled four times to arrive at 250 million at the time of Christ. Since then, up to 1975 , it doubled four more times.

We should look at the size of the populations we are doubling and the periods that it required to double. The first doubling after Christ took 1,650 years to bring us to 500 million people in the year 1650, approximately. The next doubling we did in only 200 years

By the year 1850, it had brought us to the dawn of medicine. We understood something about infectious diseases, we took better care of our children, and, also, nutrition was improving because of improvements in agriculture. So arrived in 1850 the dawn of medicine with a billion people. The next billion took only 80 years. This brought us to 1930 , shortly before the advent of sulfa drugs and antibiotics, which again greatly reduced infant mortality. All of these increased longevity, in part because of better nutrition.

The last doubling to 4 billion took us just 45 years.

What lies ahead? Population growth has been slowed in many countries, but in others it is still going on at a rapid rate. Sadly, in many of the developing nations, where already hunger, lack of education, lack of employment are very great, where population problems are greatest. The political leaders there have their hands full.

What is the outlook? Let us assume that a population of 4 billion - and we are about 4.5 billion right now - will double: If we are pessimistic in 40 years. by the year 2015; if you want to take the choice of something a little less difficult to deal with, 2035, 60 years: if you want to be optimistic, 2065 Be it 40,60 , or 80 years, we are going to have to increase food production to maintain the adequate per capita food consumption at the level it was in 1975, when there 
were estimated to be somewhere between 500 and 700 million people who were badly nourished

There are two problems. One, to produce enough food, and the second, to distribute it equitably to meet human needs. There we run into the problem of poverty, lack of purchasing power by a large segment of the world population, and its cost because of unemployment or underemployment, for the tirst basic necessity for survival, even for a few days - lood.

Why is our agriculture so productive? First of all, we were blessed with a broad base of excellent natural resources - good soil and a favorable climate. And we had creative foretathers, political leaders, and farmers. At the time of independence, our population was dispersed, about like it is in many of the third world nations today.

We were somewhere between 85 and 90 percent rural, tilling the land - a small piece of land mostly by hand. We had vast tracts of land. As our population grew, we were developing industries, also, and over the next 150 years with each generation there were better opportunities for employment at higher rates of income for many of our rural youth and they shifted to the cities.

Our agriculture was expanding in area to produce more food as it was needed in the early 1800s, but mostly by development of machinery that permitted each family to cultivate more land even though yield didn't change very much. But we did something more.

Early visionary government leaders, especially Washington and Jefferson, were tremendously interested in agriculture. I think the vision Jefferson had in the Louisiana Purchase in 1803, laid the ground work for the economy of the U.S.A. Other things contributed to its development subsequently.

There were many of these early people who added to our knowledge and who stimulated inquiry. Under President Lincoln, in a period of six weeks, there were three basic laws passed that set the stage for the revolution in agriculture production that was to come 80 years later. It didn't come overnight, and so when we look at our third world brothers, and we are impatient that they don't change their agricultural production, we have to remember that we, too, had a long gestation period and that we weren't burdened by this tremendous population monster blowing on the back of our neck as many of the newly awakening third world nations are burdened with today.

In 1862, in a six-week period, the land grant colleges were established, subsequently growing into some of our largest and most effective universities. Today, sometimes it is hard to tell whether the tail is waggıng the dog because agriculture is all too often, I think, looked down on. I will mention that in talking about the third world nations, where anyone who works in agriculture is on the lowest rung of the social, economic, and political ladder, we don't get a fair share of the talent. They want to be lawyers or doctors or chemists or engineers, and one can understand well why, when you look at the misery and the drudgery that they went through in their early lives. We have got to correct this.

At the same time the land grant colleges were established, the Homestead Act gave land to many of the immigrants who came into the country from abroad, especially those who settled on some of the worst land that possibly could have been settled on with the lack of knowledge of soil fertility. We then created this small bureau to coordinate agriculture. The Bureau of Agriculture which has grown into the U.S. Department of Agriculture after many trials and tribulations

The Hatch Act was passed because Congress was not very happy with the way things were going in the land grant colleges and universities. Reading between the lines, you can see that they were saying. "These professors don't know a hell of a lot about practical farming. They don't even know how to plow, and they're trying to teach our sons and daughters things that are worthless."

\section{"Early visionary government leaders, especially Washington and Jefferson, were tremendously interested in agriculture."}

So they set up, under the Hatch Act in 1887, the Agricultural Experiment Station mostly in juxtaposition to the land grant colleges. That began to lay the solid ground work for what was to follow.

Not much happened to change yields. The only increase in yields was the result of better machinery in the early 1800 s, which permitted more effective weed control and to conserve moisture. But the ground work had not yet been laid for fertilizer use, for improved plant varieties, better control of diseases and insects. This was to follow gradually over the next 80 years. And about the time when all the pieces of this complex jigsaw puzzle came into being as a result of good research work done by many, the other piece just collapsed. Markets, the Depression 
of the late 20 s and 30 s. And so the technology couldn't be applied. But look what happened in the years 1940 and onward with the markets developing from World War II.

What happened to production? Taking the 17 most important food, feed, and other crops, production increased from 252 million metric tons in 1940 to 610 in 1980. This was done with only an increase of 3 percent in cultivated land area.

Now, to my friends, the environmentalists, I would like to call their attention to the fact that by use of this improved technology, had we attempted to produce that amount of food, feed and fiber with the technology of pre-1940, we would have required an additional land area equal to all of that east of the Mississippi River except for the states of Illinois, Wisconsin, and Michigan. Or, we would have had the choice, of plowing up 70 percent of our range land or chopping down 65 percent of our forest and woodland. Then what would have been the cost, in erosion and in other destruction of the environment, including habitat for wildlife and all of the other issues that are played in large voices in lobbying groups of very special interest groups?

\section{"Too many people here know that food comes from the supermarket and they haven't the vaguest idea of how it got there."}

So I think we have a great deal to be thankful for, rather than to curse improved technology as too often comes out at the present time.

Now, in order to have brought this tremendous change about, it took an integrated approach with the farmer as the integrater - the farm manager, the farmer with dirt under his fingernails. The fingernails of the farmer today may be pretty well polished, but they weren't at that time. He was weaving together all of these different pieces.

Research people had to make those different. pieces of the jigsaw. They had to learn about soil science, how to restore soil fertility to the land, and in some cases it never was fertile. It was deficient in one or more nutrients. They had to develop agronomic practices to conserve moisture, to find the right dates and rates of seeding, the right crop rotations to cut back on diseases and insects and then, through plant breeding, to develop high-yielding varieties and animals that were productive in use and efficient in use of feeds. They were not only higher yielding and more efficient, but had to fit the farmer's needs from the standpoint of mechanization, to reduce risks so that they fit crop cycles to escape frosts, tolerance to winter kill, the quality had to fit industry's needs, and the disease and insect pests had to be controlled genetically or chemically. Erosion had to be kept at as low a level as was economically teasible. This now is changing with more and more minimum tillage.

This whole question of plant protection is important I think it is one of the areas where you governors come into a lot of pressure because of those who feel that we are being poisoned out of existence. I don't think that is at all true. Look at the facts. We live a longer, better, healthier life than ever before. Before this could become reality, this tremendous jump in production had to be hitched to economic policy that was stimulated by government leaders, so that the farmer could afford to adopt it and put it into practice, which in turn resulted in the tremendous jump in production. That cut across many fronts. It had to do with the availability of inputs, credit, and a fair price for the product.

I would like to mention here that the skill of the farm manager is generally not recognized today in this affluent nation of ours. Too many people here know that tood comes from the supermarket and they haven't the vaguest idea of how it got there - the capital investments that are involved in land and machinery, the technology that backs it up, and the management skills that are organized to bring all of this together to produce that food that is taken for granted.

I am a fancier of Jefferson's vision. When I see what is happening to our public attitudes towards food and how it is taken for granted, I recall Jefferson's comments in 1809 when he said, "Peace and security: were they the drugs that evaded the eternal challenge in the minds of men in other nations? And did nations, like men, grow sluggish and apathetic when they were well ted and bodily comfortable?" I think it is still a very valid question today.

Now, just to briefly try to illustrate what has happened, I will take two cases to show how difficult it is to make change.

One will be Latin America. The problem of Latin America was that it was colonized 100 years too soon. Think about that a minute. What does it mean? The feudalism that was then Spain's and Portugal's was transplanted and superimposed and shackled on the feudalism of the Aztec, Mayan, and 
the Incas. They stayed shackled with the land going in large tracts, to the privileged lew, with education for the sons and daughters only of those few privileged. not for the masses. Education was under the control of the church. The cultural transplant was made before the social-political upheavals which took place in Europe in the latter half of the 1500s, especially from 1580 onward until the middle of the 1600 s. Whereas the heritage of what is loday the United States, the original colonies, came after that upheaval and they came with an entirely different point of view. They came to have a piece of land to cultivate, with freedom to worship as they pleased, and education for all of the sons and daughters. That made a tremendous difference.

A lew weeks ago I came across a book that I think you would enjoy reading It is by Michael Novak, published by Simon \& Schuster press. In it, he talks about two conflicting points of view as to why Latin America lagged behind after independence, and Latin America obtained its independence only about 30 years after the 13 colonies obtained theirs but the control of the land, the lack of education for the masses and those who administered or were responsible for the education - that didn't change. The first country to change it was Mexico with the Bloody Revolution in 1910-20. Then, they fell into the pitfall of setting up a feudal system. The land was divided, but it was done in a way that he who used it could not own it, couid not legally sell it, nor rent it. Consequently it forced the system into one of small holdings, for the most part. They are still struggling with this result. About 75 percent of the land now under agriculture in Mexico for the most part is in the teudal system which is very difficult to manage. The incentives are not there, the investments in the land and its improvement are not made because of this system. The private farmers, such as we have here, are very progressive, but I have seen them lose a great deal of their land by invasions in the last six years. Some of the best farmers I knew that I worked with for 38 years lost every square loot.

These problems are not solved, but I do not mean to speak in a negative tone. I have worked with all kinds of governments. I have been well received in all of the countries where I have worked - socialistic governments, the so-called democracies, not in the same context as we know them here, and political dictatorships of either the right or the left, it doesn't make any difference and you find the same flaws. And yet you have to try to do what you can to develop technology that's viable and then to get to the political



Gov Ted Schwinden, Montana, Introduces panelist

leaders so that they will implement this and in the process, produce more food. The result then becomes, for the time being, one of improving standards of living.

You hope that education is catching up, but remember that this population monster affects both the abilities of nations to educate the people, and employment.

Latin America today has the mineral rights that we originally had and probably its agricultural capabilities are greater than our own here. But they didn't develop these resources. There was no creative stimulation to develop the industry or develop these raw materials, and they were inert, unused. The same way with agriculture.

The original populations in Latin America were bigger than here in our earlier colonial period. By 1940 , they were the same - about 130 million. Today, Latin America has about 366 million people, whereas we have 225 million. The rapid growth of Latin America overwhelms the school systems, the ability to provide employment. There is growing unemployment and you see many non-documented migratory workers. It is a problem of this inability to cope with this demographic explosion. Please don't misunderstand me, the Government of Mexico is very aware of this and has made a tremendous effort to try to develop industries to absorb as much of this population as possible. They are, at the present time, carrying on one of the most effective programs in demographic education. But the backlog of young people is so great that it will be 20-30 years before the pressures are lessened so that they can cope with them. And we have to try to increase food production in the meantime. We have seen a big change in the case of wheat. It went from 


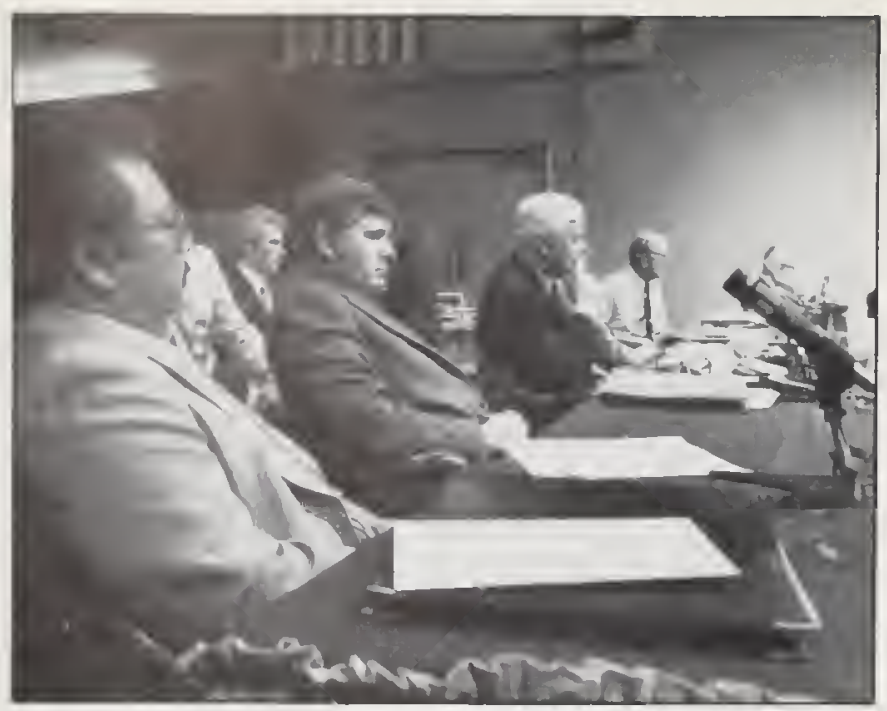

Gov Pedro Tenori (lett), Commonwealth of the Northern Mariana islands, joins colleagues at the agricultural session.

about 400,000 tons to about 3.7 million tons in 1976 . and will reach 4 million this year.

My interest is in plant breeding. I am interested in the people who eat bread, what it takes to produce that wheat, then flour, and that bread to feed the common people. I had to be concerned about breaking down all of these nice little boxes of disciplines that we find in academia here in which many of our foreign students are trained, and when we come back, we have to break apart and try to integrate. We did that 20 , or 30 , or 40 years ago, but now we have gotten very sophisticated. You have got to learn how to handle all of these things, all the disciplines, how to restore soil fertility, the agronomic practices that are most efficient for those soils in that climate, to breed the right plants, to control the diseases and insects and weeds and then to marry this all to the economic policy of government leaders who will permit its adoption by the farmer

When I started in India, I was told, "Well, you were pretty lucky in Mexico, you don't know our farmers, you'll never pull this otf." Nonsense. It went twice as fast in India. We transplanted the technology from Mexico. We modified it after 3-4 years ot on-tarm testing. We moved whole shiploads of seed and the production of wheat in India went from an average of 11 million tons - about 400 billion bushels - which is the average from 1959-66. Last year it was 37 million tons, and this year, 38 million.

Now what does this mean? More than a three-fold increase - a 300 percent increase. The additional income from last year's crop was about $\$ 5.4$ billion. If you add that up when change started to take place,
1967-68, it accumulates to somewhere in the order of about $\$ 30$ billion.

They still have got many hungry people in India. The changes started taking place later in rice. Of course when you start messing around with these kinds of things back home here, you'll get skinned and jabbed for making the rich richer and the poor poorer. That's the jargon that goes on in the scientific literature. I think it is pretty largely motivated by political ideology. Maybe they would like to see a revolution coming, and go left rather than to see as we can't get this ball rolling tast enough, so that it can evolve democratically. If you are going to be involved in this, as a scientist, a foreigner working abroad, you need to develop a skin slightly thicker than that of a rhinocerous or an elephant. That way you don't feel all the darts or you ignore them. And if you can develop bad hearing, it's also pretty useful.

When you showed the results of tests on farms, to prove the validity of your case, I never saw more enthusiastic farmers, though the vast majority were illiterate, but that doesn't mean you can't figure if you're illiterate. You see that it's going to yield twice or three times as much as before, sometimes more. And if the government makes fertilizer available at a tair price, they take oft. India became in 1979 self-sufficient for the first time since independence. In addition, they had 22 million metric tons of grain in their warehouses. Then came the worst drought in 90 years. Rice production plummetted and the next wheat crop, because of the shortage of irrigation water, went down by 4 million tons. But we never heard anything about hunger. They lived otf those 22 million tons in storage. We would never have been able to move 22 million tons through the ports, assuming they had the wealth to buy it, or over the railroads, and back up to the villages. And we didn't even hear about it in this part of the world.

So, in closing, let me say that, we can stave off the population monster while we double this food production and some more. We shouldn't only increase it in the next whatever it turns out to be, 40,60 , or 80 years, from 3.3 to 6.6 , but we have got to do better - perhaps 7.3 billion metric tons, because there are still too many hungry people. We have got to do a better job of distributing it. It is a very complex problem I say it can be done. We shouldn't get led oft the path by special interest groups who are sure we are poisoning ourselves out of existence, who are more interested in recreation. I told you at the outset that I lived the back country of Idaho and I learned to 
know myself there. It is still one of my great interest - forestry in general. I think in my second reincarnation I am coming back as a forest geneticist. But that might worsen this population problem.

I say, yes, it can be done, it we don't get led oft the track. If we have the fertilizer available - and that calls for energy imports - if we have fair pricing for our products and visionary government leadership, it is possible. Let's not become complacent and through foolish legislation increase the cost of food production so that we get priced out of the market like the automotive industry. I'Il quote the president of Tufts Universty who now is the head of nutrition at Harvard. A few years ago he said. "Few scientists think of agniculture as the chief or model science. Many indeed do not consider it a science at all. The first science. The mother of science. It remains the science which makes human life possible. And it may well be that before the century is over, the success or failure of science as a whole will be judged by the success or failure of agriculture."

I thank you.

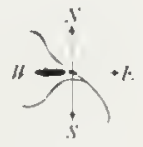

31 


\section{Food in the West Open Discussion}

(Governor Lamm): Dr. Borlaug, magnificent, thank you. When the history of these times are written, I think it will show that you and the Green Revolution gave us the breathing room that we then immediately went ahead and didn't take advantage of. Ultimately, the stork will fly faster than the plow. We do have a serious problem of balancing population and resources, and I very much endorse what you are saying

Other comments, questions? I would like to make this as informal as possible. Our panelists are up front and I would like to turn to the governors for questions or comments, whatever else.

Yes, Governor Atiyeh.

(Governor Atiyeh): Dr. Borlaug touched on it, but maybe he or Dr. Castle could speak further on it. I am aware that the average age of the farmer is increasing, which means that the younger people, for a variety of reasons that we might understand, are not moving into agricultural production. What is the implication of this trend? Can the situation be reversed?

(Dr. Castle): It is just too competitive of a business for any large amount of inefficiency to prevail for any significant period of time. So, I guess, I don't see it being reversed. I don't see any public policies that would change what I think is a fairly fundamental trend.

"It is just too competitive of a business for any large amount of inefficiency to prevail for any significant period of time."

Although, I certainly think it's most important that we maintain the agricultural research and extension establishment that we've had and that they do have special programs for those who would like to enter agriculture.

But hopefully, I would advise them to come in on a realistic basis and, I think the worst thing in the world would be to attract a lot of young, inadequately financed people into an industry that is really very, very, competitive and requires the very best in managerial abilities. That's a somewhat long-winded answer, Governor, but I think those are items that have to be taken into consideration.

(Dr. Borlaug): Let me just add one point to this and you have to remember I may be answering this out of stupidity and ignorance. But, I think that the inheritance tax laws as they stood up until very recently, were one of the kisses of death for the small family farm, and certainly this has contributed to the confusion. I believe there has been some correction of this, is that not correct?

(Mr. Bressler): Well, over a long period because it still hasn't reached a desirable effect yet, but at least we're moving in the right direction.

(Dr. Borlaug): About the age of farmers, I would just like to say that I just came back from Poland about three weeks, a month ago, and through coercive pressure of many kinds to socialize the land there over the last 30 to 40 years, it hasn't flown because of the great resistance. Still 75 percent of that land is in the hands of private farmers. They're all small. They look like Indian farms - five to ten acres

But, the same problem of aging is going on there. Virtually all of them are 60 years or older. The youth have left because of the pressures of uncertainty of tenure and lower incomes. The prices have been regulated to force the private sector to sell out, and receive, in turn, some kind of retirement. What that is worth on paper or in real lite is beyond me, but there 
you can see this pressure is very great. I think it is a very sad situation.

(Governor Schwinden): I am fascinated by your hypothesis of the transplanting of the Spanish feudal system on Latin American and the impact it's had Do you draw any parallel at all, Dr Borlaug, to what appears to be a movement in that direction in this country?

Let me just point out, I guess, my own hypothesis is that, you mentioned that the people who came here in the 17th and 18th century brought with them a whole variety of things, but primarily an interest in acquiring a piece of land and doing their own thing. And, as early as 1787 , we had already embarked upon an educational process.

And yet, 200-plus years later, the trend is completely the other way. Over the last 60 years, we've lost over 40 percent of our tarm units in the State of Montana. One of the major issues, I think, in every one of our states is the role that private education ought to play.

Do we face a time when the control of food and agriculture in the West is going to follow the same path as energy? Are we going to have the agricultural Exxons and the agricultural Burlingtons, Dick, and Allantic Richfields, in which, just as the energy of the West is now under the control of relatively few multi-national corporations, the same thing will happen in a feudal kind of transplantation of the West

(Dr. Borlaug): I am very glad to hear this question posed. I must answer it in two different ways because I think the question of time frame is important here.

(Governor Schwinden): You're the politician, then, with two different ways to answer it.

(Dr. Borlaug): No, it has two different facets. For example, one of the great strengths of the agricultural revolution here in the last 40 years has been the inputs of the agribusiness - the whole gamut of things they have contributed - fertilizer production, distribution of technical services, various kinds of seeds, hybrid seed companies, a whole series.

In most of the countries where I have worked, it is a government monopoly and it's rotten with politics not politics as much as corruption. And, when you get into this kind of a situation, no matter how good the technology, the efficiency of how it is applied is at a very low level.

Now, let me point out the danger. There's no question in my mind, but what is anachronistrc in this case, ownership of large tracts of land in Latin America. A good case in point is Argentina, even today, or Brazil in opening many of these new lands.
There's many of them that are 50-, 60-, 70-thousand acres or more. And, this poses a real problem down the road because ihere are many who are landless, and there is going to be social or political upheaval unless we can help those who are miserable to at least get the basic ingredients for a decent life.

So, we've got to balance this. We can go overboard, I think that you political leaders have a real responsibility both at state level and through your influences in tederal government to try to permit these changes to take place in an orderly way Certainly, the small fragmated farms are gone, and they weren't such a pleasant way of life either. I know from personal experience.

But, the one paper that I forgot to point out to you is, "Why Latin America is Poor." It's by Michael Novak and this is one chapter out of his book published in Atlantic Monthly in March of this year. Quite curiously, I arrived at the same conclusions. In 1965, I gave a series of lectures across Canada that said that Latin America was born 100 years too soon. The manuscript got burned by an accident in the office, so it never appeared, but as early as that I could see there were some big obstacles here that were in the transplant.

And if you look back to the home country, the development has only started taking place in the last 30 to 40 years in Spain and Portugal. So, the shackles were late in coming off and it takes a long time to catch up.

(Governor Lamm): Any other of the panelists like to respond? Governor Ariyoshi?

(Governor Ariyoshi): I was very interested in some of the comments here about the importance of agriculture and in our state we happen to teel this is

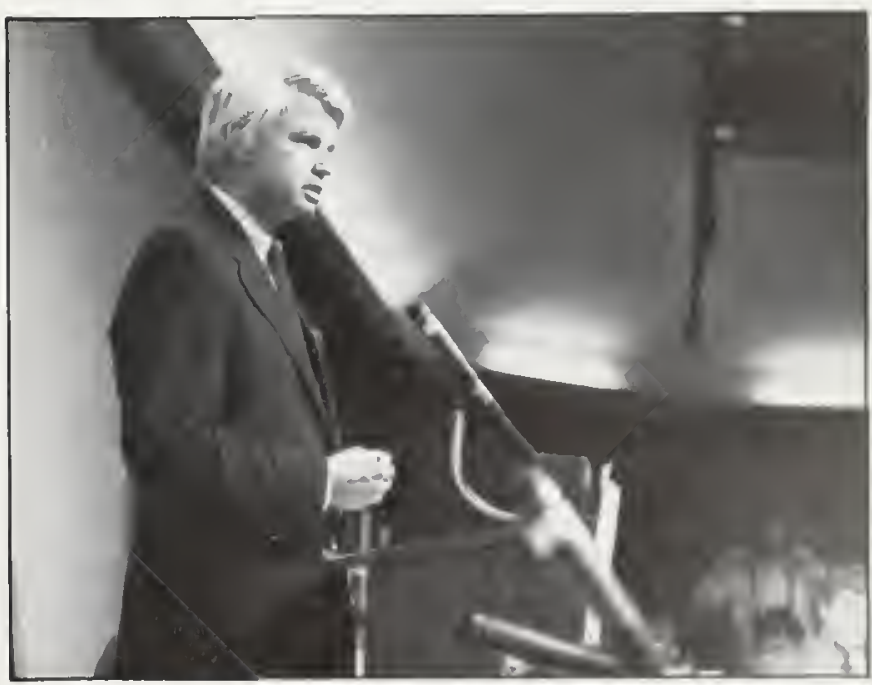

Gov Aichard Lamm, Colorado, handles queries from the audience. 
important from yet another perspective. We're a state greatly involved in tourism. We feel that visitors, when they come, should have a good experience and we must have a lot of the open space and must maintain that open space. And because we don't have that much land, agriculture provides a use of vacant land, land that is open space, productive land that produces dollars and jobs.

I think, in connection with the comment about farmers getting older, if we assume that every farmer, and those who follow them will want to get into agriculture, I don't think it will be the kind of problems we would be facing today. But, we need to recognize that not all children of farmers want to become farmers. You have a problem of new farmers trying to come in who don't have the land and who don't have the capital to get started. We think that it's important for that to be addressed.

What we have attempted to do in our state is try to provide some government land. We have state land that is not being used productively today, wasteland, and we have attempted to put in some water and some of the amenities, roads, in order that we can tell farmers to come and they can tarm as long as they want to. The land will be used tor agricultural purposes, and it will be an agricultural rate so that they can, indeed, farm these lands. And we think that is very important

We think also that a very cruel thing for us to do is to bring farmers on and not have them be able to market what they produce. We believe that it's very essential for the marketing side to also be addressed. Growing the right crops and growing them at the right time, and not having everybody going at the same thing and having everything mature at the same time, and have the bottom price drop out. We think that cooperatives are very important for this effort. We think that it's important for government to get involved in some of the marketing efforts, and this way we can attract many people.

We have in our state many young people who want to get involved, but they find it difficult to get involved because of the non-availability of land, and because when farmers don't have their children who will take on their business, they start looking at their retirement, and land that is used agriculturally. They start looking at how they can get more out of this land now that they are retiring. How can they maybe get it urbanized so that returns will be greater. And we teel that is a problem that is very important and needs to be addressed.

(Governor Lamm): Yes, Governor King.
(Governor King): Dick, I think that the panel did an excellent job. All of you ought to be complimented I'm sorry that the Secretary of Agriculture, John Block, was not able to be here today to go through this fine panel and also make his presentation of the problems that he sees and is trying to solve. But I think there are two things that we certainly should transmit to the Department of Agriculture.

One is the strengthening of the dollar as it affects and applies to imports or exports. So, I think that we definitely need to try to resolve this as much as possible. I know that it's a long-term type of problem and situation, but we want to continue to point that out, Dr. Castle, that we understand the situation.

Another subject that was pointed out also today, was the fact of the high cost of money and need for capital to operate agriculture. This again is a long-term situation that will be difficult to resolve, and ! hope that as we discuss the budget we will try to encourage the Congress and the administration to resolve and come up with a budget, because I think this does have a long-term effect.

Those are two things that I specifically think we will have to address and we will have to reckon with if we are going to improve the economy of agriculture.

(Governor Lamm): Yes, Dr. Castle.

(Dr. Castle): I would like to comment on that. As an agricultural economist who also studied some about macroeconomic policies, it has always seemed to me that this is one of the most neglected areas in public policy. We go about setting macroeconomic policies with very little concern to the regional impact, to the industry impact.

In this country since World War II, we have had eight business cycles and if you trace the history of those business cycles, you will find, I believe, that each time we have increasingly depended on monetary policy as a way of controlling inflation. Now that may be necessary if we have nothing else. But it seems to me that we do have something else, and I feel that unless we break this trend that we're going to have tremendous effects on forestry and on agriculture.

As a matter of fact, I would argue that in the forestry and housing area, the impact this time has been permanent. It has not been temporary. There has been a permanent long-run impact of the present monetary situation, so I do think you put your finger on an exceedingly important problem and one which I think needs lots of attention and one which I think has been neglected both in the public policy arena, as well as in the academic arena. 
(Governor Lamm): Governor Olson.

(Governor Olson): I would like to make an observation and ask Dick Bressler to respond Family farms are efficient in production and, I think, notoriously inefficient in defending their position in the market.

As we move toward more transportation, with which I agree, we lessen competition in moving our products to export, especially in Ted's and my state's products.

What guarantees can you, as the president of $\mathrm{BN}$, give us that when we have moved to subterminals and consolidating and centralizing the gathering of agricultural products and once we have sort of reduced the competition for transportation that you won't, or your company won't, sir, change the rules of the game at that point and perhaps take advantage of your competitive position.

(Mr. Bressler): Well, as you know, Governor, one of the concerns of our company has been the loss of market share that we've had in the State of North Dakota. We've tried to rectify that by being more competitive and we think we have regained market share. They're principally, of course, against the trucking interests.

I think that you'll never see the complete lack of competition there and I make the point not only with grain but any other commodity that our railroad hauls. We don't make money by not hauling something, so we recognize that if we want to see export grain move to the Northwest ports, which is very instrumental in our well-being as well as it is to the farmers in North Dakota, we have to make sure that that flows. And I think we will. Those forces are going to be there.

(Governor Lamm): Yes, Governor Atiyeh.

(Governor Atiyeh): If anyone would like to respond to the question of the use of agriculture as a tool in foreign policy. I think our wheat industry was devastated by an embargo that effectively took away the market, because Russia then sought other places in the world to buy their wheat. Some comment earlier about, I think Dr. Castle mentioned that, that when we announce an embargo policy that it makes even our regular trading partners nervous. I know how I feel about it, but I would like to have some comments from anyone who would like to speak to that issue.

(Dr. Castle): I do not feel that I am a foreign policy expert, but I do think there are some things that can be said about this. With the world demand-supply situation for grains or such, it's exceedingly difficult for one country, even the principal grain exporting country, to unilaterally take action and have great effect. What typically happens is that someone else makes up the shortfall.

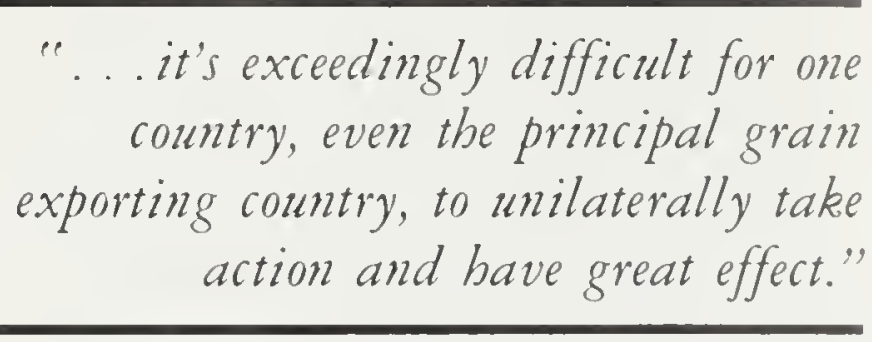

I think that grain is very different than petroleum. It may be possible, although it's been temporary, for the oil exporting countries to get together and set some prices and control production on a unilateral basis. But, I think it is very, very difficult to do this in the area of agriculture and grain.

That isn't to say that our state department people should be ignorant of agriculture or the realities of agriculture, nor that our strength here should be ignored, but it is to say that I think embargoes against one country are very difficult to impose and enforce and be made effective.

(Governor Lamm): Yes, Governor Ariyoshi.

(Governor Ariyoshi): I think that a number of you have been to Japan and have been part of or involved in selling agricultural products and I think there are some market problems there too. But, one of the things to really talk to the Japanese about when they want to talk to you privately is the problems they went through. They were a country that went through starvation during the second World War, so they know what hunger is all about. And they had a 1973 soybean embargo that the United States imposed on them and that has left a deep, deep scar on the Japanese. And if you talk to them in private, and try to get their real feelings, they say to you that they know what it is to have gone through some hunger. They know what it is to have gone through a period when they had a very important commodity taken away from them and not sold to them. Therefore, they do not want to be facing a similar kind of situation

One of the reasons why they feel very strong about their agricultural products is that they do not want to be under the control of some other nation and I think this embargo thing is a very, very important thing to them, in this particular instance at least.

\section{(Governor Lamm): Dr. Borlaug?}

(Dr. Borlaug): I agree with the comments made by the Governor of Hawaii. I think that the soybean case is an excellent example to show that it didn't work 
then and what we have tried last year on grain embargoes were essentially restrictions, let's say, rather than embargoes. The Soviet Union just turned to Argentina and I knew full well how much was in the warehouse. I have worked with the Argentine government, the Brazilian government, in the case of soybeans.

Japan, as a protection against shortages, has worked very closely with both Brazil and Argentina since that embargo and so our market is in jeopardy on soybeans. This comes along now on wheat and corn and it doesn't help us either.

I have a teeling that somewhere or another, we don't have very good communications between the State and the Agriculture Departments. Now, before we make decisions I'm talking about in our federal government, we shouldn't make them precipitously. I agree that embargoes are ineffective except in time of total war. Then you get an alignment to stop this like in World War II. But in ordinary times, where there are social upheavals in one country or invasions, there are too many ways where grain is transshipped, and ends up in the place where it wasn't intended to go, in any case, or another source comes onto the market.

(Mr. Bressler): I think the problem, Governor, is that our State Department still doesn't understand what has just been said here. Untortunately, that still has the predominant influence over trade policy.

\section{(Governor Lamm): Governor Bruce King}

(Governor King): I would just like to say that as we have the trade negotiations this fall with Japan that we would remember to address these subjects and try to expand that market in the agricultural fields to Japan. It should be very important to us and I call to balance the production and to not have the surpluses

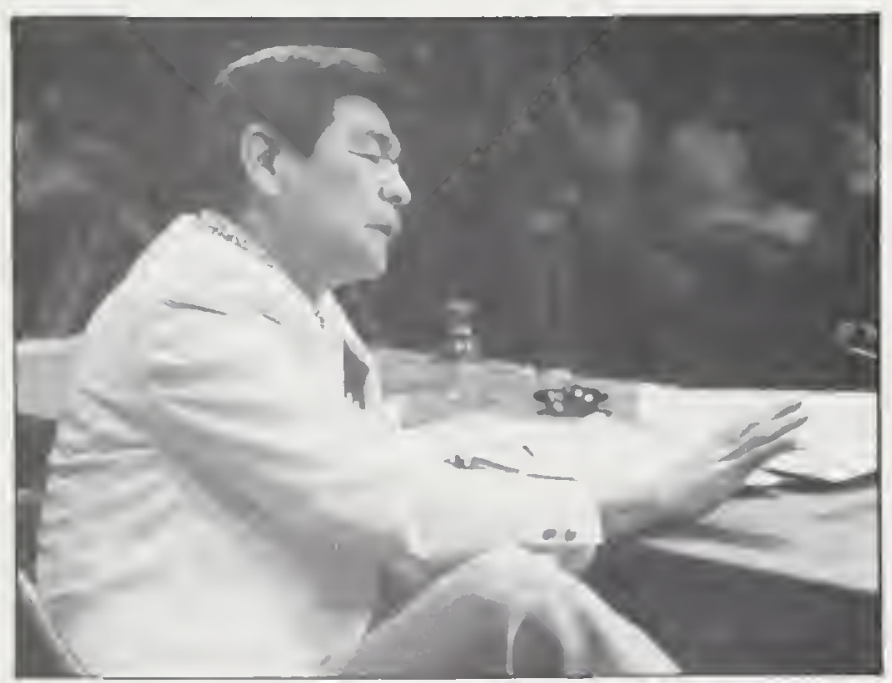

Gov George Arlyoshı, Hawall, makes a point that always continually press the market down. And that's the other two sides of this coin, the high interest and strengthening of the dollar. It not only hurts in that area, but also depresses the market due to an excess in production

(Governor Lamm): Governor Herschler.

(Governor Herschler): I am just wondering it any of the panelists might care to comment on how vital research is in sustaining the growth in agricultural productivity. What the role of the states should be?

(Dr. Borlaug): If you permit me, I would like to speak to this point because without it, we're licked Withoul good, strong continuing support for research. we're going to be losing ground all the way it has to be research across a broad spectrum of disciplines.

To illustrate that, the varieties that are bred and developed and distributed, whether out of Oregon State University or Washington State University or any of the other agricultural experiment stations, with or without the collaboration of the U.S. Department of Agriculture, are short lived They're going to become susceptible to diseases sooner or later, and if you don't have research backing it up either in the private sector or in the public sector, you're going to have tremendous losses and the only way to hold this back, these losses, to cut them, keep them at reasonable levels, is by continuing research in both the private sector and in the industrial or in the public sector. So, that's a must. Yet, research funds are drying up.

I have seen some very interesting things that have been helpful across nations as a result of a hell of an epidemic of stem rust in 1949,50 , and ' 51 across the US, and Canada. We set up an arrangement where all of the state experiment stations from spring wheat region, bring their materials to Mexico and the U.S. Department of Agriculture into Canada. And they grow winter nursery and take it back and this has been going on since 1951. It cuts in half the time that is required to produce a new variety.

In the same token, we're working with Oregon State in developing winter wheats for third world nations. The feedback is two ways. It might be surprising to some of you that many of these wheats that were developed in Mexico found a home in California and New Mexico and Arizona. They are grown commercially in those sizable areas. We work with the scientists in those places.

(Governor Lamm): Now, we have Dr. Castle and then we'll go to you.

(Dr. Castle): The organization and management of research, public research, in agriculture has been a 
special hobby of mine tor a number of years I spent 21 years in a land grant university and was trained in a land grant university. I think that there are some very important problems here and I would like to just identify what I think they are.

I think it's terribly important that we maintain the investment in this area and federal investment has been declining. States have increased their investment in agriculture and certainly they are to be complimented for that. There is a great deal of pressure being put on the land grant system, from the federal establishment generally, and it's my feeling that we're going exactly the wrong way.

I think what is happening here is that, because of the great concern about accountability, the system is being coordinated to death. Some of the very most able people are spending all of their time trying to take this very loose system, coordinate it, and present some kind of a plan to the Congress that proves that there's no duplication and there's no overlap. I think the strength of this system historically has been its decentralization. I do not believe you can organize research for the entire land grant system from Washington, D.C., or from any central point. It's the Dr. Borlaugs working in the local area that make the difference, and so I think that there's great danger here.

At the same time, I think that the federal government has a major responsibility in agricultural research, and l'll just mention two areas I think some investment in basic research often has to be underwritten by the federal government because I think no one state can be sure it's going to get a return on that kind of investment. And so I think the amount of basic research is needed. We cannot expect to get it entirely from the state and I think the area of national agricultural policy is a peculiar responsibility of the tederal government.

I think that what is happening at the present time and there has been a real trend in this direction in the last ten years, is to try to push the system into a straight jacket, a blueprint from Washington. I simply think that is going to be counter-productive with respect to agricultural research.

I apologize for the little speech here, but it is an area which I feel very keenly about and I certainly think, whether I am right or wrong, it is an important area that the governors should be very well aware of

(Governor Lamm): Governor Olson.

(Governor Olson): Correct me if I'm wrong, but I think the Farm bill had some provisions that responded to the embargo problem. There is, I believe, compensation required if we embargo in the future. At a minmum, there was at least a response to the embargo problem which may bode well for the future.

It's been my observation that states have just two areas that can affect their agricultural well being marketıng and research. It may be my only concession to the New Federalism in the sense that we are going to increase our research in North Dakota and also some dollars for marketing.

In '81, we funded a Northern Cross Institute of North Dakota State University which will be for the purpose ot quite similar institutions around the country, Dr. Castle, to emphasize the crops grown in our part of the country, but in research I hope it will be more than symbolic in a very tight budgeting situation that we will enhance dollars available for research. But I suspect it will be very parochial.

We grow premium wheats in North Dakota even though we were the number one wheat producer last year. That was because Kansas had some unfortunate experience with weather. We grow premium wheats and we have a ditficult time marketing them worldwide where the emphasis is on its pricing. So, we'll be parochial and somewhat selt-serving in our research and I'm concerned that while we're emphasizing the high protein potential of North Dakota wheats, we may be losing a sense of the quality, baking quality, the quality of gluten and this type of thing.

We're concerned there. We'll be parochial and I guess that fits, Dr. Castle, with your approach. And that is why I would like to see a fairly general agricultural policy for the United States. I'd like to have it speak to the embargo issue and to set some goals For the nation it seems to be the only industry that we retain a basic strength in worldwide. No one can compete with us in agriculture, and it's because of the things that Dr. Borlaug indicated

But, within that larger policy framework, l'd like to be able to, as governor of North Dakota, to look atter our particular interests within that large policy for the United States. It's an observation, but l'd like to see us doing something about it at the Western Governors' Conference, because it has been a stable thread throughout our existence out here, Dick, as you indicated. We need work on it.

(Mr. Bressler): Governor, I would just like to comment on your remark on the provision in the legislation that tried to accommodate the tarmer in the event of an embargo. Then it gets going in the wrong direction, because that doesn't do anything for the customer. It's the customer that we're worried about because he is the fellow that ultimately is going to 
mean the success or failure of our agricultural industry.

(Governor Olson): That's a good point. Of course, initially, as governor of North Dakota, I'm worried about losing these in the first place.

(Governor Ariyoshi): Mr. Chairman, because these are some important gentlemen, l'd like to do some lobbying and especially to make some comments, because of the comments prompted by Dr. Borlaug about the ocean in terms of energy, fisheries and mining of the ocean. I think there is tremendous potential there. The other comment I want to make was no one has talked about aquaculture here. I think there is a tremendous potential in our country for aquaculture.

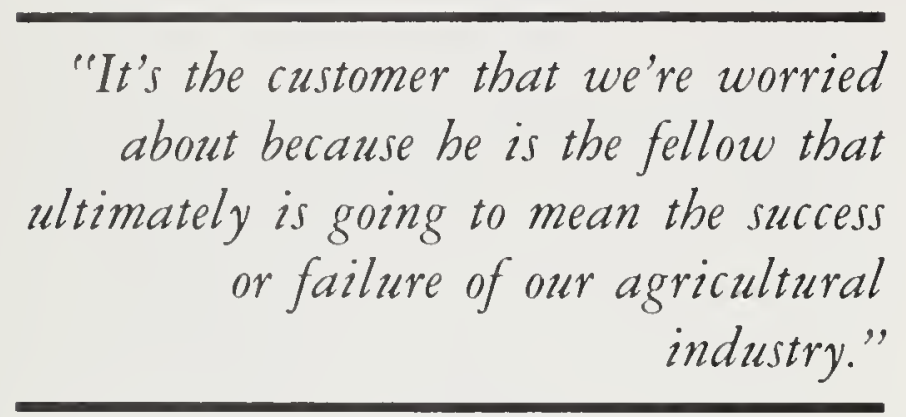

Two weeks ago I announced in Hawaii that we were having the first salt water shrimp farm - in the planning design stage - commencing in our state. This is a project going to Mexico and, with the help of the University of Arizona, a great deal of research has been done. We first started off in our state trying to promote a great deal of aquaculture. We have an oyster farm right now in existence that can mature an oyster in nine months that will take three and a half years in any other part of the world. I really feel very strongly about the prospects for us to be able to farm in the ocean. Aquaculture, I think, is a very important part of food production in the future of our country.

(Governor Lamm): Governor Spellman.

(Governor Spellman): I don't really want to take exception, but I want to understand what Dr. Castle said. He laid out the urbanization of agricultural land as not being a problem. The shortage of water as not being a problem in the ' 80 s. The lack of energy being more significant than those, but not the substantial problem, and the environmental side of it also not being a significant problem. The only problem being of creativity Now, I assume you're talking in the short-term, because in my mind each one is a significant problem.

(Dr. Castle): Yes, each and every one of them are significant problems and they're going to continue to command our attention. What I was trying to do was to look at the supply of agricultural products that might be exported and look at it from that point of view. And from that context, I certainly can't see the conversion of agricultural land as being something that's going to have a major impact on exports. I think that the water area is potentially a more important one than the land area. I don't think that we're going to have the growth in agricultural production from increased irrigation in the future to the extent that we had in the past.

On the other hand, I don't see a massive water shortage for the nation as a whole. With respect to energy, my only comment there is it's going to affect all commercial producing areas in about the same way because we do have a world energy market. So any country that's going to be exporting grain is going to be faced with higher energy costs if they prevail in the future. If you look at where our increased agricultural production has come from in the past, it by and large has come from increased yield per acre and trom increased productivity, and so if we don't keep new techniques coming on line we don't maintain our basic production plan and I think we're going to lose ground competitively in the international field. And regardless of what we do about our natural resources, land and water, I think we'll lose ground if that doesn't occur.

So, it is not to say that these are not important problems. It is to say that if we're really concerned about our competitive position in agriculture, we must look at productivity, new technology, new discoveries, and that's why investment in research, 1 think, is so terribly important.

(Governor Lamm): I would add one to that, by the way. Also, look at birth control. I mean you can't have supply side agriculture forever.

(Dr. Castle): I focus my remarks almost entirely on the supply side because I thought the world demand side was coming up but...

(Governor Lamm): But no one ever mentions the other one.

(Dr. Castle): No, you're quite right. But one of the very encouraging things that has occurred, and I believe Dr. Borlaug will comment on this, is that if you look at what's happened to birth rates in Latin America, in South Asia where agricultural production has increased, it's an encouraging trend. The runaway birth rates are occurring in those areas where there has not been great breakthroughs in agricultural production. For example, Africa and the Caribbean and some places like that

(Governor Lamm): Dr. Borlaug, let's turn to you, it 
sounds like you wanted to say a piece. What, do you figure there will be 35,000 more people when you sit down to dinner tonight than when you got up from breakfast.

(Dr. Borlaug): Since we sat down at this conference, there's roughly 25,000 more people that need to be fed. If they aren't fed, there's an old Spanish saying that "a full stomach and a happy heart" and I add right after that, an empty stomach, be careful. The world political upheavals come as a consequence of this and for more than 25 years going on 30,1 have been advocating that you've got to balance both halves of this equation. Now, many of my Mexican friends, longtime friends, say, "Why didn't you speak in a louder voice in those early years?" I said for the simple reason that I would have been thrown out of the country if I had spoken too loudly, too early.

Now, there is this awareness, but the distortion in the population is such that there is 55 to 60 percent of the population 17 years and younger which means that as these people mature and marry, this population grows even though the numbers of children per family will, I think, fall rather dramatically in most areas where there's agricultural development going on and industrial. It will take 20-30 years to get past this.

Let me add one other thing that worries me to no end, Governor Lamm. The use of land, multiple versus single use, I think we have to watch this.

Then, also another issue, when we get our back to the wall on the energy issue, petroleum for example, and I appreciate the situation of the farmer with the deflated prices. But gasohol, and I've looked at this carefully in Brazil, when made from sugar cane what's happening? First, it's highly subsidized and it's



Gov Allen Olson, North Dakola, raises a point. displacing tood crops from the best land, pushing them right out and this is virtually impossible to control with these high subsidies that are involved. I'm very feartul that if we went too far on our own ethyl alcohol from corn that we would upset the whole world trade in feed for livestock in the long run. How soon this is will depend on availability of other sources of energy, but something's got to be done. You said there is energy that's basically in wood for conversion to liquid fuels by one or two different processes. That calls for a lot more research and calls for adjustments in prices that will take place as petroleum becomes more scarce.

Governor Lamm, I think that you might be back in business over there with those shales sooner than you think if this situation in the Near East continues to deteriorate. We'll probably be back on the front burner with all of that and hoping we will continue right on through.

(Governor Lamm): Great, thank you. To close our morning session, then, Governor Schwinden. 


\section{Closing Remarks}

\section{Ted Schwinden}

\section{Governor of Montana}

Thank you, Dick, and I want to especially thank the panelists who I think have given us this morning an opportunity to explore not only food in the West, but agriculture in terms of the entire world. In closing, what l'd like to do is to try to bring back the perspective of the original theme which is the West and the role that we have as governors.

Dick Lamm started out by saying that agriculture is the glue that holds the West together. It that's the case, then I believe the question that Dr. Borlaug asked earlier in terms of a louder voice on behalt of Western agriculture is something that clearly is needed. But we're expected to do that in terms of a declining farm population. Obviously, a lesser political voice and perhaps most dangerously of all, another point that Vic Atiyeh mentioned this morning was the fact of the 55 years of age and the impact that this can have on agriculture in the future. I think the other side of that question is really more important. That's that we now have generations of Americans who are below 55 who have never had a rural experience. The Jeffersonian Idealism is tough to implant on Wall Street or in Los Angeles. We have a population, at least in this country today, which overwhelmıngly views agriculture I suppose somewhere between "Little House on the Prairie" and "Dallas." Given that, I think we have some real problems down the road

There is an excellent paper that was prepared for our conference by Mr. Ehrenreich from Idaho, and I suggest that the Western governors use that to ask ourselves the question: it indeed ag is the glue of the West, then perhaps it is time to elevate it to an area of concern and sensitivity. Here in the 1970 s we have concentrated on energy and its implications because of not only our region, but the world Clearly, as Mr. Ehrenreich pointed out, the West must begin to act in concert as a region on both agricultural and other natural resource issues

I think it's a challenge that we began discussing this in depth today with the participation of Dr. Borlaug, Dick Bressler, Dr. Castle, Governors, and the people here this morning. I think we've got an indication of the challenge ahead If we're going to continue to maintain agriculture as a key element, not only in the West but in terms of feeding those additional, I suppose it's up another 2,000 by now, people, hungry people around the world Thank you.






\section{Section Two \\ Food in the West Prepared Reports}

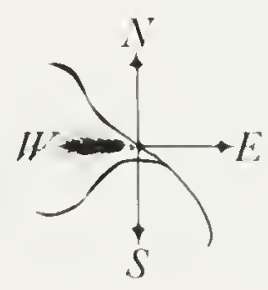




\section{Introduction}

The essays included in this section were designed specifically for the "Food in the West" program at the 1982 Western Governors' Conference at Gleneden Beach, Oregon. The opinions offered are the product of the individual authors, not the Western Governors' Conference, the National Governors' Association, any individual governor, nor any state official. The preparation of these essays - by individuals in the West or with roots in the West - combined with the actual event at Gleneden Beach had the intent of stimulating thought and action on a variety of agricultural and agricultural-related issues for years to come.

Joseph A. Kinney

Producer

Food in the West 


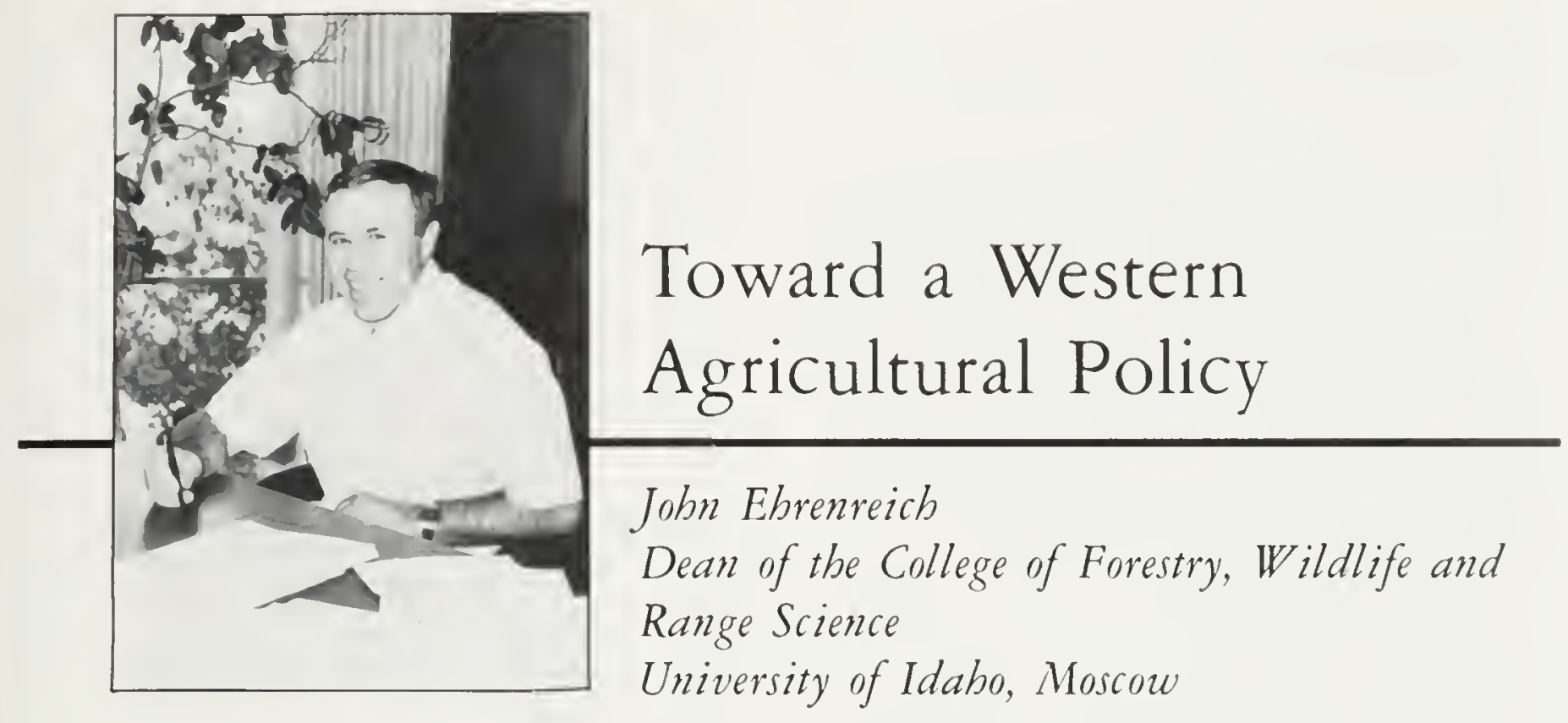

$\mathrm{T}$ he United States is entering a period of more profound change than has been experienced in the past 40 years. Nowhere is this change more evident than in the development of our agricultural industry and the management of our land based natural resources. Agricultural technology must continue to remain in the forefront if the United States is to produce sufficient food to sustain its people and world demands by the year 2000. Yet this need presents itself at a time when the ability of the economy to maintain a viable agricultural industry is becoming increasingly marginal. Population growth, diminishing energy reserves, world tension, and economic and social change all mean that at the same time our technological capacity adjusts to meet our needs, our socio-political institutions and responses must be different and in a new context from the past.

Agriculture in the western United States presents a unique challenge to these conditions. Western agriculture is faced with the same general problems as agriculture in the nation: water; transportation; availability of land; development of domestic and toreign markets; and adequate prices to offset the increasing costs of production. These problems are presented, however, in a context different from other regions of the nation. Agriculture in the West is tied inextricably to national natural resources. While not formally recognized as such, agriculture must be seen as a component of the multiple use management of the vast public lands of the West. Any decisions made tor the development of agricultural lands or increased production are limited not just to the authority of local citizens or officials or state governments, but also to decisions made by Congress concerning the management of western forests and rangelands. Yet the Mountain West in particular, because of its sparse population, is not represented by large congressional delegations; these conditions existing in states where agriculture remains a dominant portion of individual economies.

The West, and western agriculture in particular, has always perceived itself as being exploited by larger national forces, either private or public or combinations of both. Most of our national laws and policies to stimulate agricultural growth and development were enacted to satisfy different farming conditions from those in the West. Government regulation of the public lands has been seen as an attempt by power blocs in other regions to manage property they neither understand nor directly use. Current proposals to sell vast amounts of public land still leave the West in the same position, only the perceived exploiters this time are large multi-national corporate interests. This development, if it occurs, will be at the expense of western agriculture, again, all at a time when the need for efficient food production is critical.

Over the years, the West has come to perceive itself as a victim rather than a partner in the development of national policy. To survive, the agricultural community has developed a deep sense of independence which, while building a strong cultural identity, 
has precluded presenting a united tront to state the case to the Nation for western agricultural needs and problems.

Agriculture in the West has been forced into a somewhat Faustian role in the sense that to maintain a viable economic base and cultural identity, we have called for industrial development which potentially has the most deleterious effect on our agricultural strength and stability. While feeling victim to forces beyond our control, we have been forced into a kind of "politics of hysteria" in which commodity is pitted against commodity; rural citizen against urban citizen; state against state; the states against the federal government; and the private against the public sector.

This trend can be reversed but it will require new approaches in confronting the problems. First, we must confront the problems directly. We must treat the causes and not the symptoms. Economic growth at any price to stimulate the economy to help keep agriculture strong will ultimately weaken agriculture. The real issue is what will be required to strengthen and enhance agriculture? How much tood will be required in the coming decades? Who can produce what best? What markets can be developed? How can those qualities unique to western agriculture be enhanced? What relationships can be developed among states and between the states and tederal government to make the West a full partner in national policy as opposed to perceived victim? In short, there is a need for a western agricultural policy: where are we; where we want to be; and what we will need to get there over the coming decades. Only if such determination is made individually within states and in the West as a region will we be able to sustain western agriculture as we know it. The most advanced technology in the world will do no good if tarmers cannot afford to utilize it or it it alters the cultural foundations that have kept tarming and ranching independent. Unilateral decisions made in Washington, D.C., to declare the development of energy potential on the public lands to be a priority will not be effective if that development takes place at the expense of our capacity to produce the necessary tood and fiber to maintain ourselves as a nation. Each decision must be made in the context of its effect on another and that cannot be done without a true assessment of needs and goals. Decisions on how we manage our torests and wildlite have an effect on agricultural production just as where and how we mine or drill for oil and minerals. More than any other region in the nation. agriculture in the West is a major component of our concept of multiple use of natural resource management and more than any other time in our history that management must take into account projected national needs for those products that enable us to sustain life.

There are specitic things which can begin to take place if agriculture production and technology are to keep pace with national and world needs. First, the producers of individual commodities must become more united in articulating western agricultural needs, whether in the development of new markets or in the management of natural resources.

Second, state governments and their respective departments of agriculture must become more policy oriented. In those states where agriculture is a dominant force in the economy, determination must be made as to what will be required within states to sustain that economy. Few states in the West have that capacity at present.

Third, state governments must strive to develop a partnership role with the federal government in the management of our natural resources. Only through such a decision making process can the unique qualities of the West to produce food and fiber realize their full potential to benefit an entire nation.

Fourth, the West must begin to act in concert as a region on agricultural and natural resource issues. Certain individual commodities have begun to do so, but no interstate association of governments, nor any group representing western agriculture in general, has developed any component to deal with agricultural needs shared in common by the region - and this in a region where agriculture is the foundation of most state economies.

If agricultural technology, production, and income are to keep pace with one another in the western United States, we must preserve and maintain agriculture as an independent force. But no longer can we operate that force within a vacuum. A vehicle must be created whereby our basic needs for food and fiber are determined in a context which enables those needs to be met to the fullest potential.

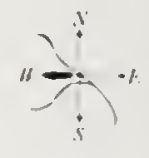




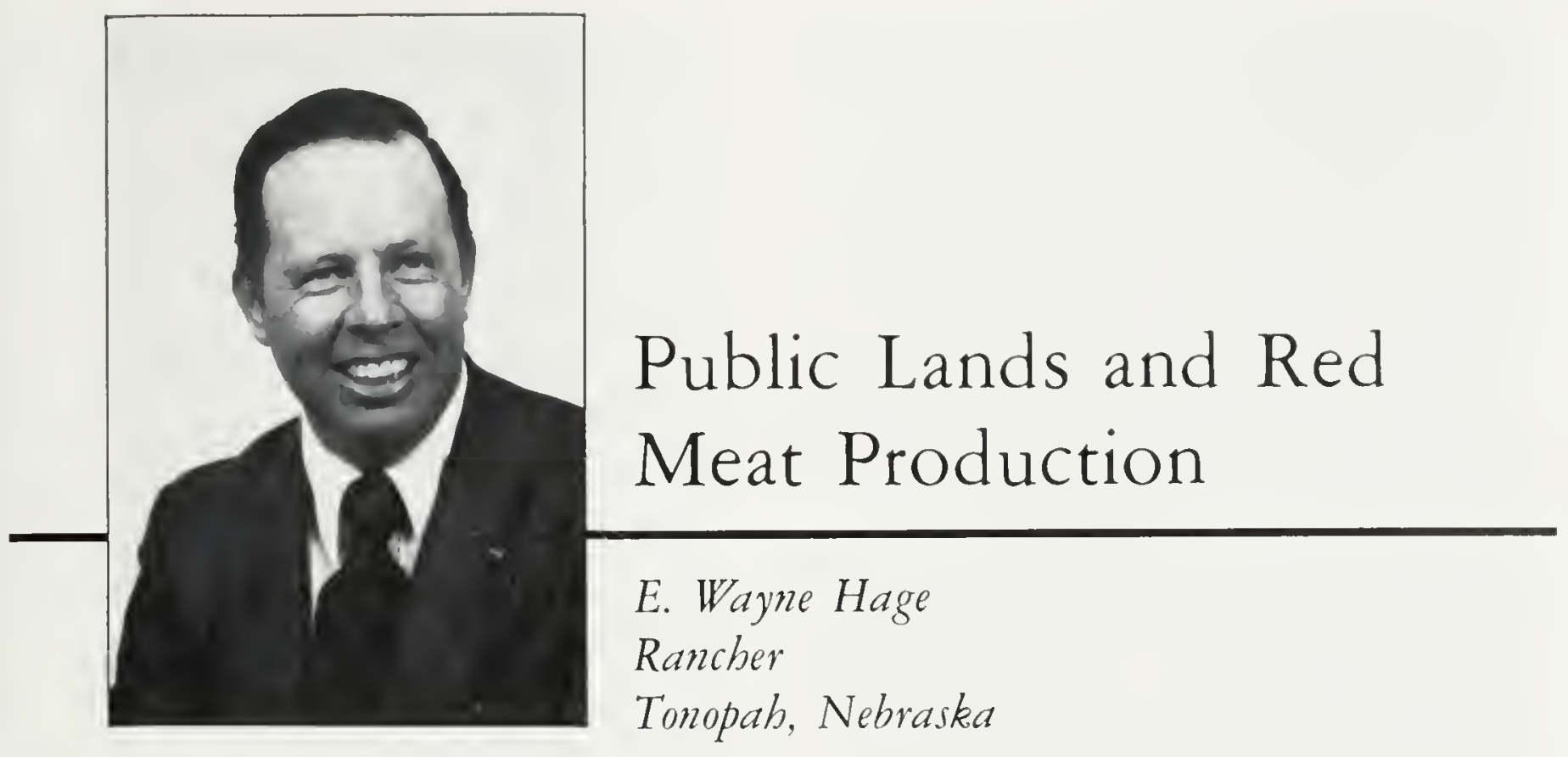

$\mathrm{N}$ issue facing the western cattleman today has greater potential for long term increase in tood production than the public lands tenure issue. A failure to resolve the public lands tenure issue has the potential to continue the erosion of food production efficiency to the point of elimination of the public lands livestock industry.

To examine this potential consider that approximately one-third of the land area of the contiguous 48 states is controlled by the tederal government parks, wildlife reługe, Indian and military reservations - but these constitute only a small portion of the whole. The majority of these lands are used for grazing domestic livestock and are under the jurisdiction of the Forest Service and the Bureau of Land Management

These public lands of the western United States produce 22 percent of all the feeder cattle in the United States. Government and private studies agree that the lands are producing much below their potential

These lands act as a giant solar collector. No fossil fuel is expended in tillage and cultivation. Perennial grasses and shrubs as well as many annual species grow naturally. Harvesting is accomplished without the direct expenditure of fossil fuels. Livestock grazing these rangelands accomplish this task through their natural lite processes. As tossil fuels become more scarce and the cost of energy as a whole increases, these energy etficient grazing lands of the West become more significant.

Prime croplands of the United States are being converted to non-agricultural uses at a very rapid rate As more and more conversion of our cultivated cropland takes place, there is an increasing need to convert other prime potential croplands currently being used for livestock grazing to field crops. This increases the need tor the full and efficient utilization of our energy efficient western ranges for red meat production

To further underscore the potential of our western rangelands consider the economic impact of these lands on our economy. Every cow grazing tor one month on our rangelands produces a $\$ 70$ to $\$ 135$ impact on the regional (multi-county) economy as shown by Oregon State University studies. It would be worth our time to briefly review how the impact is generated

\section{DISCUSSION}

Forage without a means of harvesting that forage has no forage value. Much of our western range area was originally in that condition. As the land was settled ranchers developed support tacilities for livestock operations throughout the range areas. Where water was available for irrigation, riparian areas were expanded to produce supplemental forage for the winter months. Where no water was available, wells were drilled, springs developed or water hauled to 
allow livestock to utilize the range. These support facilities on today's market cost between $\$ 9$ and $\$ 10$ on the average for every cow grazing one month on the public rangelands as shown by University of Nevada studies. Added to this cost is a current $\$ 1.86$ grazing fee paid to the federal government, bringing the total cost to the rancher for grazing one cow for one month on the public rangelands to over $\$ 11$, higher than the typical cost of private pasture.

The major portion of the money expended by the rancher to support his ranch operation, excluding the grazing fee paid to the federal government, is spent locally. It pays for food, wages, insurance, parts, equipment, etc. Depending on the multiplier effect for the given region the economic impact of that one cow grazing for one month is between $\$ 70$ and $\$ 135$. Carried beyond the regional level to the national level the economic impact multiplies. Multiplying the number of months livestock utilize public lands and subsequently multiplying by the economic impact of each animal, demonstrates the multi-billion dollar contribution livestock grazing makes to the nation's economy.

Thus far we have referenced two main points: livestock grazing on our public rangelands is energy efficient and (2) livestock grazing on our public lands contributes to our nation's economy.

Let us look briefly at the future of this industry. Decisions in the next 10 years will largely determine whether we maximize the efficiency of production on these lands or whether one of our most promising resources becomes an economic liability

\section{"Decisions in the next 10 years will largely determine whether we maxi- mize the efficiency of production on these lands or whether one of our most promising resources becomes an economic liability."}

For a century a three-way struggle has continued for control of the vast public lands. States have argued they should have control of the lands within their borders. Commercial interests claim established rights and argue for control. Federal government land management agencies maintain that states and private interests are not capable of wise management

So strong has the federal lobby for retention of these lands been that over the last 100 years there has been a complete turn-around from the original laws that favored distribution of the lands into private and state ownership to perpetual retention of these lands and acquisition of new lands where possible.

This has created huge and growing problems for the West's livestock industry. From the 1880's the General Land Office effectively lobbied to prevent formal property rights being transferred to the range user. Attempts by ranchers to develop separate fenced ranges to enhance management and protect the resource base was opposed by the Forest Service and by the General Land Office. The Forest Service later agreed to support separate ranges among ranchers in return for rancher support for the transfer of the Forest Service from the Interior Department to the U.S. Department of Agriculture. Federal agencies feared that the development of efficient separate ranges among ranches would establish a property right interest in that range and eventually lead to the end of the federal land management agencies.

Ironically, the states did own the non-navigable water arising within their borders. Ranchers in turn could obtain ownership of the water by proving beneficial use for livestock or irrigation purposes. A standoff, so to speak, was reached The states and private interests controlled the range by virtue of the fact they controlled the water. Range without water is of little value. The federal government land management agencies also recognized the significance of the fact and have worked diligently in recent years to legislate and regulate their way around this impasse.

The 1960's brought an array of legislation to strengthen the federal hold on the public lands, each bill effectively decreasing the efficiency of forage production through increased regulatory cost. Some of these major pieces of legislation were the Multiple Use Act, the Wild Free Roaming Horse and Burro Act, and the Federal Land Policy and Management Act (FLPMA).

The Multiple Use Act adversely affected the public lands rancher by attempting to equate nonmarket uses of the public lands with market uses such as grazing, a concept which has since been proven invalid. A nonmarket use such as recreation cannot be valued in the strict sense. Its worth can be determined through a replacement cost approach.

Attempts to place nonmarket uses of the land on par with market uses has placed costly regulatory pressure on the rancher who often encounters major disruptions of his operation by favoring the nonmarket use. Wise management can in most cases accommodate both uses. 
The Wild Free Roaming Horse and Burro Act has been used to justify massive and sometımes destructive herds of feral horses on our rangelands. The rancher paid for range rights when he bought his ranch as a part of the ranch price. His range boundaries have been set by agreement, adjudication, legislation, priority use and commensurability with land owned in fee simple. The rancher owns the water rights without which the range would be worthless for livestock. The rancher sustains a cost of trom $\$ 9$ to $\$ 10$ a cow per month to maintain his animal and range. The rancher pays the federal government approximately $\$ 2$ per cow per month in grazing tees. Yet the rancher in many parts of the West finds his range being severely overutilized by herds of teral horses and burros, the control of which has been prevented by inaction by federal agencies and protests by groups of wild horse enthusiasts who have nothing at economic risk in the issue and pay nothing for the use of the range by the excessive horse numbers their actions have created

The FLPMA has been viewed by the federal and management agencies as legal justification for challenging state and private rights on the public domain lands. The agencies have viewed FLPMA as a vehicle to override state control of water rights and to gain absolute control over the lands. Attempts to use the lederal reserve water doctrine to supersede state control of water was stopped by court ruling in 1981 There are, at present, attempts by the Forest Service to invoke a federal nonreserved water doctrine of doubtful validity to override state and private control of water. All of these actions lead to increased cost of production on the part of the rancher. Non-cost effective management plans created by the Multiple Use Act to accommodate non-market uses of the lands have often reduced or eliminated livestock grazing.

Likewise, the Wild Free Roaming Horse and Burro Act has taken vast amounts of forage from our rangelands for which there is no marketable return to the public, and, oftentimes, at the expense of severely damaging the rangelands themselves. Ranchers who have for generations worked and invested to protect and enhance their rangelands have in some cases found their ranges under threat of devegetation of key forage species. One rancher in south central Nevada incurs a yearly uncompensated cost of $\$ 45,000$ to pump water for the feral horses that have encroached his range.

The use of FLPMA to challenge state control of water rights has forced many ranchers to take legal action to protect their interests. The cost of litigation to protect rights on the public domain is a cost against the anmal unit month of forage on that range. Federal action agaınst state and private rights on the range can easily double or triple the cost of grazing on the public lands

At the same time the federal agencies have been struggling for total control of the ranges, they have effectively stopped any significant investment by the tederal government in range improvements. The uncertainty of the situation created by the continual challenge of the ranchers' rights on the public lands has effectively stopped any private investment on the rangelands.

Documents supplied by the federal land management agencies in the early 1970's relating to range conditions suggest that government control of the rangelands has led to a deterioration of those lands. The agencies have supplied data in the development of the Resources Planning Act demonstrating that tederal administration of the range is not cost effective

We can therefore reference a third point. The efforts by the federal government to supersede or eliminate various state and private rights on the public domain lands threatens the long-term cost effective productivity of those lands.

\section{SUMMARY}

What are some of the possible solutions to this apparent dilemma? Maintenance of the status quo would appear to result in a continual erosion of the economic viability of the public lands livestock industry

Another possible solution would be socialization of the public lands. The elimination of state and private rights on the public domain lands would allow the tederal agencies full discretion as to how the lands would be used Although this alternative would bode well for the longevity of the federal and management agencies themselves, tederal agencies do not have a good record of operation on a cost effective basis.

State control of the ranges has been suggested as an alternative to tederal control. State control could provide a viable alternative to federal control as long as the tenure issue was recognized and the states did not allow the development of a non-cost effective bureaucracy to administer the lands. The tenure issue could be dealt with in a manner similar to water rights Continual beneficial use of the range would guarantee the property right interest in the range. This would stabilize the livestock industry and stimulate private 
investment in the resource base.

Privatization of the public lands is being suggested as an alternative to the present tederal control. Privatization, recognizing the existing private and state rights on the public lands, could be the most viable alternative of all. History and numerous studies have demonstrated that public control of natural resources is the most inefficient use of these resources. Private control stimulates the most efficient use of resources.

\section{CONCLUSION}

We have suggested three main points in our discussion.

1. The public rangelands of the West are very energy efficient for food production.

2. Livestock grazing makes a major contribution to our nation's economy.

3. Continued federal control of our public rangelands threatens the viability of efficient food production trom those lands.

The federal land management agencies argue that their continued existence is justified by virtue of the need to protect other multiple use values on the public lands, such as watershed, historical sites and wildlife There are none of these values that are not already being provided for, or could readily be provided for, by state and private interests.

It is logical to conclude, given the growing world population, population shifts from east to west, the growing energy crisis and potential food shortages that the resource riches of the public lands of the West will be developed.

The real question is will they be developed under a system ol private enterprise or under a system of federal government control<smiles>CC(C)(C)C</smiles> 


\title{
Agricultural Innovation
}

\author{
Jobn Freivalds
}

Editorial Director of Agribusiness Worldwide Minneapolis, Minnesota

I the United States and spread eastward, technical innovation in agriculture seems to be repeating this pattern. Western agriculture faces many challenges, notably limited rainfall and distance from markets, and in an effort to minimize costs has developed innovative technologies in order to stay competitive.

\section{MULTIPLE CROPPING}

The longer growing season in many western states has led to innovations in multiple cropping. In California some 200 crops are grown, so the possible combinations during any year are almost endless. The multiple cropping systems, however, have to consider the compatibility of crops, farm chemicals and farm machinery. This has been done successfully in many areas, allowing farmers to maximize net returns per acre.

\section{COMPUTERIZED FARM MANAGEMENT}

Western agriculture is heavily capitalized and to gain maximum use of these resources, a growing number of California farms are now using computer programs to design their tarming operations.

Software packages developed for western agriculture are now finding their way into other regions of U.S. agriculture Computer programs have been developed to allow more efficient use of machinery, optimize irrigation scheduling, develop least-cost animal feed rations, and design multiple cropping systems.

\section{IRRIGATION}

To many social observers, water may be the national issue in the 1980s that energy was in the 1970s. Water is in short supply in many western states, and it is well known that agricultural development in many areas is impossible without modern irrigation systems. Several systems are now in use in the West: modern surface, hand-move sprinkle, center-pivol sprinkle, and trickle.

These systems are constantly improved to deliver the most water at the least cost. As a result, modern surface is giving way to sprinkle and drip systems. Drip irrigation is a convenient and efficient means of supplying individual plants, such as trees or vines, with low-tention soil moisture sufficient to meet demands imposed by envirotranspiration. A drip irrigation system offers special agronomical use of land and water Allainable field efficiencies range from 90 to 95 percent.

\section{MECHANIZATION}

Technology in the West has produced remarkable machines, from fruit pickers to tomato and pineapple harvesters. Huge power tractors, such as the models manufactured by Steiger in Fargo, North Dakota, and Big Bud in Havre, Montana, have been developed for larger western tarms. While the use of this machinery has raised the capitalization of individual farms, it has lowered unit costs

To make this new generation of machinery more efficient, enormous progress has been experienced in 
land preparation technology. Now, laser guided machinery is used to level land to exacting tolerances.

Another mechanical innovation under development is a system tor mechanically transplanting crops. A commercial system is available tor several vegetable row crops, and research and development is underway to create a system tor the ornamental and forestry markets.

The core of the system is a plant growing medium which allows the first fully-automatic transplanting of a seedling into the field. The entire system includes a planting plug (composed basically of peat moss held together by "glue"), a special tray in which the plug is formed and handled, a new tray seeding machine, a new greenhouse growing system, and a new, fully-automatic transplanter

\section{INTEGRATED PEST MANAGEMENT}

Instead of relying solely on chemicals to eliminate insects, advanced pest management programs employ many approaches. Integrated pest management systems using a range of cultural, biological, mechanical and chemical measures have been developed for cotton, rice, apples, alfalfa, potatoes, pears and wheat in the West.

\section{LIVESTOCK FEEDING AND PROCESSING}

The Western states have developed the foremost cattle feeding systems in the United States. Feed ratios have improved significantly due to better feed formulations, improved management, new veterinary systems, better design of feedlots, and the location of slaughtering plants near the feedlots.

The new slaughtering plants have provided such innovations as circular pens to cut carcass damage, and single floor operations to improve processing efficiencies. As a result, the terminal markets in urban areas are now part of American folklore.

\section{POST-HARVEST HANDLING AND PROCESSING}

Innovation has been the hallmark of post-harvest handling systems, particularly for high value fruits and vegetables. Deterioration of fruits and vegetables begins immediately after harvest and to slow this process, field cooling systems have been developed Fruits and vegetables are put into field coolers with temperatures around 50 degrees where "tield heat" can be significantly diminished
The major logistical problems faced by Western agriculture in reaching the populous markets of the East have resulted in the evolution of an intricate, technologically sophisticated complex of farm assembly and marketing systems involving such diverse methods of food preserving as retrigeration, drying, fermentation, freezing and canning This tremendous superstructure adds value to the on-farm income at a multiplier rate estimated to be at least three to one.

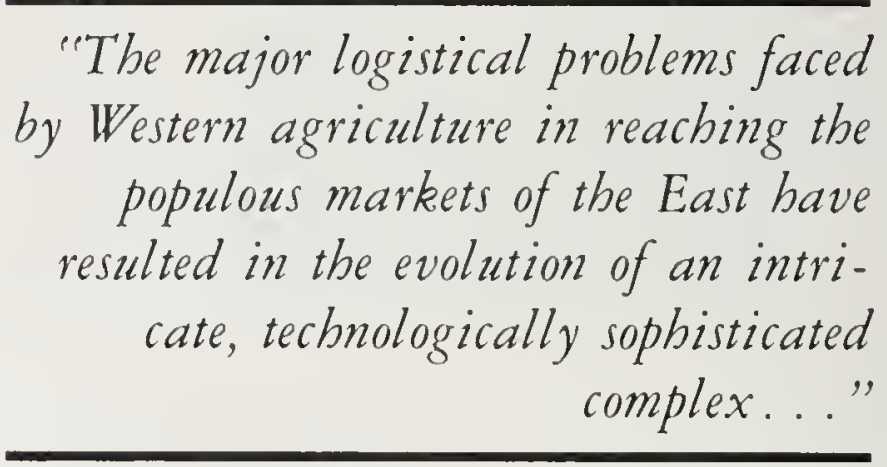

\section{SEED VARIETY DEVELOPMENT}

The resources of the western agricultural experiment stations and private agribusiness firms have led to a large and growing pool of seed varieties. This has resulted in increased yields not only in the West by all around the world from seed exports. Whether it is tomatoes for processing in the San Joaquin Valley, grass seed trom Oregon's Willamette Valley, or alfalfa from North Platte, Nebraska, the constant improvement of seed has kept Western agriculture improving.

\section{CONTROLLED ENVIRONMENT AGRICULTURE}

Due to the high cost of water, a number of companies have been developed in the western United States to advance controlled environment agriculture, often referred to as hydroponics. Water savings are tremendous with this type of operation. For example, one company uses just 5.8 gallons of water per pound of lettuce produced, compared to 50.4 gallons in a more traditional farming setting in the Imperial Valley.

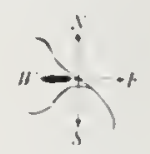




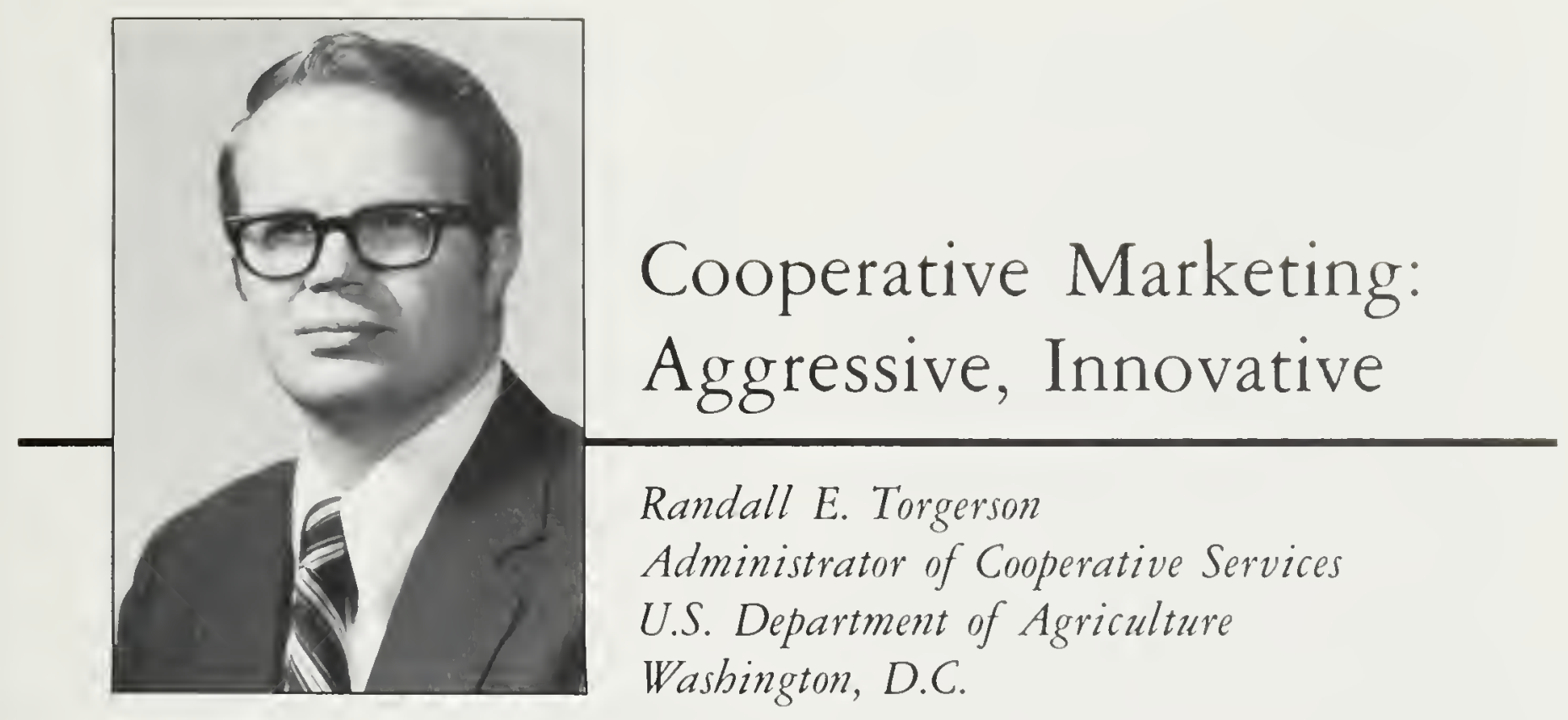

Y

ou seldom could get through the day without benefiting in some way from western cooperatives.

Sunkist oranges, Blue Diamond nuts, Sun-Maid raisins, Sunsweet prunes, Tree Top apple juice, Norbest turkeys, Calavo avocados, C\&H and American Crystal sugar... these are just a few products by name. Additionally, other western cooperatives are major marketers of cotton, dairy, grain, rice and, most significantly, a host of tresh and processed fruits and vegetables.

Western cooperatives have been the traditional marketing leaders for U.S. agricultural cooperatives. Their innovative and aggressive operations have made many of their names and brands household words nationally, and in a few cases, internationally. They account for a substantial portion of total cooperative business volume and they are a major influence in western agriculture.

California is the centerpoint of western cooperative activity. Latest data available, 1979, show California third nationally, in combined marketing, farm supply, and related service volume. The state's $\$ 4.2$ billion accounted for 7.5 percent of total U.S. cooperative volume. North Dakota (included in this group), with $\$ 1.4$ billion, and Washington, with $\$ 1.37$ billion, are other leading states in this region. The combined volume of 14 western states exceeds $\$ 10.3$ billion, or 18.3 percent of the $\$ 56.3$ billion U.S. co-op volume.

North Dakota had by tar the greatest number of cooperatives, 431, and memberships, 179,225. Combined, this western region accounted for 1,282 or 19.9 percent of the 5,445 U.S. total number of cooperatives; and 685,069 memberships or 12 percent of the 5.6 million total memberships.

Major commodities marketed in the western region, in order of importance, are truits and vegetables, grain and oilseeds, dairy, sugar, cotton, rice, livestock, and poultry (table 2). The first three commodities each exceed $\$ 1.5$ billion; the remainder much less than $\$ 1$ billion.

As a group in 1980, these western region cooperatives account for 24.7 percent of the region's total marketing activity for the commodities they handle Western cooperatives' largest share is for sugar, 60.7 percent. Shares indicated in table 3 are at the first-handler and are for the combined number of cooperatives handling the commodity.

As examples of marketing leadership, Sunkist was advertising as early as 1895 , even in export markets. The cooperative claims to be the first national advertiser to mention vitamins in its copy - an ad in the January 14, 1922, issue of Saturday Evening Post. Sunkist holds several patents associated with citrus processing Calcot, Ltd, discovered a way to reprocess cotton motes (short fibers left on seed atter ginning), previously considered trash and burned. Instead, the reprocessing in the $1979-80$ season returned $\$ 3$ million to growers

Several cooperatives have been innovative in energy. Verendrye Electric Cooperative in North Dakota is running its 30 -vehicle lleet on a fuel blend of sunflower and diesel oil. California Almond Growers 
and Diamond Walnut have installed cogeneration plants to generate electricity by burning hulls. The cooperatives can supply their total heat and electricity needs and sell excess power to area utilities.

Historically, western cooperatives have been active in exporting. Of 63 cooperatives involved in direct exporting in 1980, 26 were from this section of the country. Major commodities were fruits, vegetables, and nuts; cotton; grains and oilseeds. The western contribution to U.S. co-op direct exporting is evident in the fact that the largest number of cooperatives exporting from a specific commodity group was 22 fruit cooperatives with direct exports valued at $\$ 408$ million.

Western states, particularly in California and Washington, dominate the nation's fruit and vegetable bargaining cooperative activity. Data compiled in 1978 indicate the nation had 34 negotiating associations with 15,700 members producing crops valued at more than $\$ 850$ million. Western states accounted for 22 associations with 10,900 members and crops valued at nearly $\$ 680$ million. Calitornia and North Dakota are both significant states in bargaining activity for sugarbeets.

Table 1 - Cooperative numbers, membership, business volume for selected western states, 1979

\begin{tabular}{|c|c|c|c|}
\hline States & Co-ops & Memberships & Business volume \\
\hline & & umber & $1,000 \mathrm{dol}$ \\
\hline California & 245 & 70,340 & $4,260,930$ \\
\hline North Dakota & 431 & 179,225 & $1,427,767$ \\
\hline Washington & 129 & 81,661 & $1,367,071$ \\
\hline Oregon & 60 & 62,308 & 720,706 \\
\hline Colorado .. & 84 & 44,857 & 708,309 \\
\hline Idaho .... & 62 & 43,461 & 509,787 \\
\hline Arizona . . & 21 & 98,818 & 488,404 \\
\hline Montana & 143 & 65,716 & 376,502 \\
\hline Utah & 33 & 21,823 & 328,305 \\
\hline Wyoming & 23 & 7,538 & 55,599 \\
\hline New Mexico & 23 & 5,432 & 47,700 \\
\hline Hawaii & 23 & 3,686 & 29,523 \\
\hline Nevada & 4 & 156 & 18,656 \\
\hline Alaska & 1 & 18 & \\
\hline Total & 1,282 & 685,039 & $10,339,259$ \\
\hline
\end{tabular}

Table 3 - Combined share of the marketing activity, western cooperatives, by commodity, 1980

\begin{tabular}{|c|c|c|}
\hline Commodity & $\begin{array}{l}\text { Number of } \\
\text { Co-ops } \\
\text { handling }\end{array}$ & $\begin{array}{l}\text { Percent of region } \\
\text { total at } \\
\text { first-handler level }\end{array}$ \\
\hline Sugar & 19 & 60.7 \\
\hline Dairy & 50 & 43.2 \\
\hline Grain & 430 & 37.2 \\
\hline Rice & 4 & 30.3 \\
\hline Fruits, vegetables, nuts & 208 & 28.4 \\
\hline Cotton & 69 & 25.2 \\
\hline Poultry & 8 & 7.4 \\
\hline Livestock & 47 & 6.5 \\
\hline
\end{tabular}

\section{SUMMARY}

Use of cooperative business organizations by ranchers and growers in western agriculture accounts for a significant amount of business activity. This activity manifests itself through domestic as well as international market activity, often involving branded products. Western cooperatives are characterized by more individual centralized commodity marketing organizations than is true in many other parts of the country where diversified farm supply/marketing organizations are found.

Cooperatively owned businesses provide ranchers and growers with a voice in the marketplace and an opportunity to add value to on-farm production. Vigorous marketing initiatives have paid off by providing stronger production units and economically healthier rural communities. Cooperation is an idea that works in western agriculture. 
Table 2-Cooperative business volume, major commoditıes markeled, selecled states, 1979

\begin{tabular}{|c|c|c|c|c|c|c|c|c|c|}
\hline \multirow[b]{2}{*}{ State } & \multicolumn{9}{|c|}{ Commodities } \\
\hline & Rice & Nuts & $F / N$ & Cotton & $\begin{array}{c}\text { Grain } \\
1,000 \text { dol. }\end{array}$ & Dairy & Sugar & Liveslock & Poultry \\
\hline California . & 163,600 & 328,538 & $1,586,799$ & 426,716 & 16,098 & 689,214 & 424,129 & 1 & 55,990 \\
\hline North Dakota & - & - & 16,583 & - & 858,936 & 58,704 & 96,298 & 40,907 & - \\
\hline Washington & - & 1 & 404,754 & - & 381,939 & 233,528 & 867 & 1 & - \\
\hline Oregon.... & - & 1 & 181,204 & - & 94,194 & 170,978 & 1 & 1 & \\
\hline Colorado & - & - & 14,748 & - & 160,436 & 101,959 & 49,015 & 188,883 & - \\
\hline Idaho & - & - & 113,462 & - & 92,800 & 128,282 & 34,606 & 20,847 & - \\
\hline Arizona & - & - & 80,595 & 160,881 & 1 & 1 & 667 & 1 & - \\
\hline Montana & - & - & 1 & - & 182,623 & 12,990 & 21,341 & 7,249 & - \\
\hline Utah & - & - & 2,726 & - & 7,200 & 131,891 & 12,069 & 1 & 25,529 \\
\hline Wyoming & - & - & 1 & - & 5,659 & 10,210 & 4,071 & 2,450 & - \\
\hline New Mexico & - & 1 & 1 & 21,462 & 9,232 & - & 100 & - & 一 \\
\hline Hawaii ... & - & 1,920 & 9,650 & - & - & 1 & 2 & - & - \\
\hline Nevada & - & - & - & 50 & 1 & 12,522 & 137 & - & 4,758 \\
\hline Alaska & - & - & - & 二 & 1 & $\dot{1}$ & - & - & - \\
\hline Total & 163,600 & 330,458 & $2,410,521$ & 609,109 & $1,809,117$ & $1,550,278$ & 643,300 & 260,336 & 86,277 \\
\hline
\end{tabular}

' Disclosure would permit identifying individual cooperatives.

2 Included in California volume. 


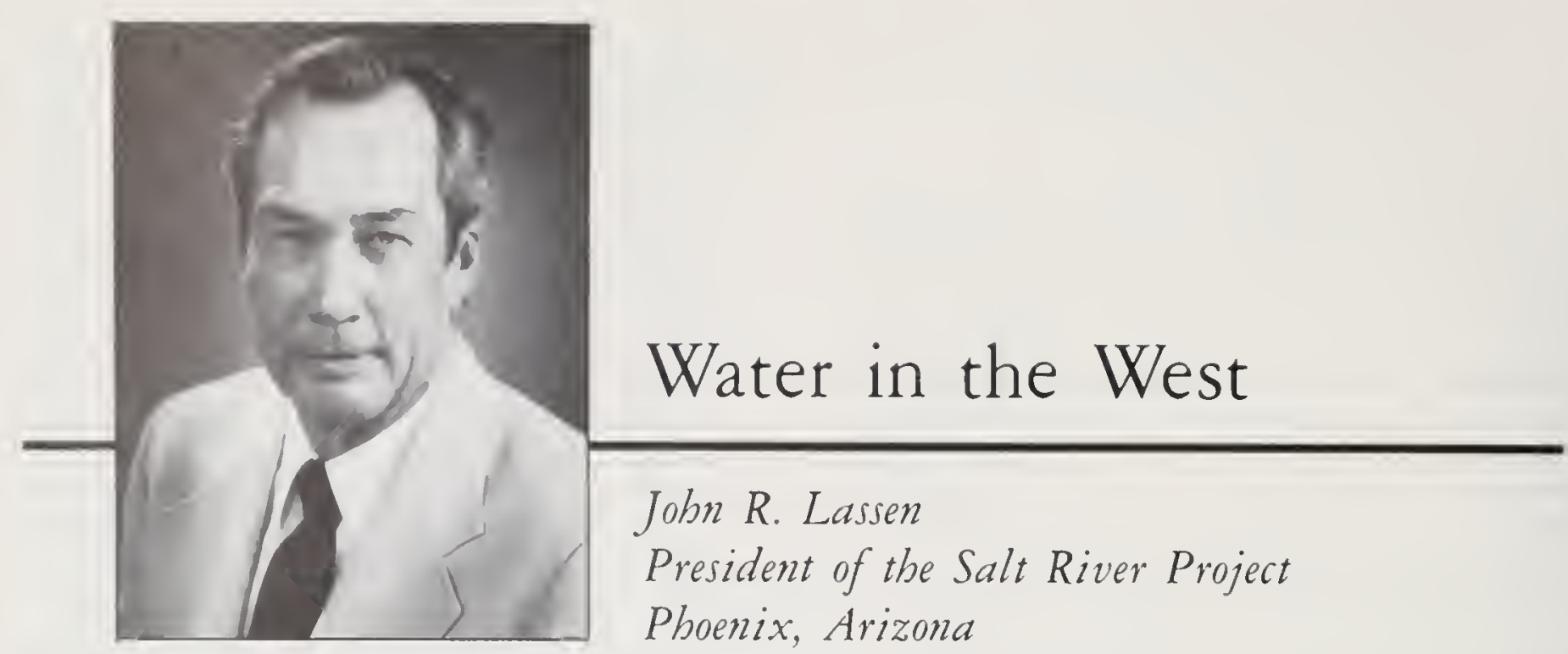

W

ill Rogers was absolutely right when he advised young people to buy land, "because the good Lord's not making any more of it."

But he might have added, "Be sure that it has a good water supply because land without water is useless."

Rain is scarce in the 17 western states, which comprise 50 percent of the U.S. land mass. These states receive only 19 percent of the national precipitation

In my area, the average rainfall is about seven inches a year. That's rather paltry compared to 38.9 inches of annual precipitation for Washington, D.C.; 40 inches for New York City; 42.5 inches for Boston; and 34.4 inches for Chicago

So it's no surprose that many of the major cities in the West are connected to some kind of reclamation project or reservoir system. And many of those that aren't connected are making plans to do so

Consequently, "supply" issues took priority in a recent poll of western water experts.' The top ten issues according to the respondents were drought, ground water depletion, ground water contamination, competition among water users, surface water contamination, soil contamination, flooding, water rights conflicts, decaying distribution and treatment systems, and degradation of coastal and wetlands areas

I am certain that water issues will become the focus of national attention in the 1980s and 1990s in the same way that energy issues held the spotlight in the 1970s

There are three main reasons for this, and they are interrelated. First, there is the increased migration of people to the West from the East and the ancillary "Snowbelt versus Sunbelt" reaction among some members of Congress. Second, in these difficult economic times, there is likely to be decreased federal funding for reclamation projects. Third, competition will increase among water users for both existing and tuture supplies

Regarding migration, it's true that people are continuing to move to the West from the East. This is a process that has been occurring since the days of the Pilgrims. The West always has been the "national satety valve," a place tor those who are down on their luck or those who are looking for greater opportunity

Trying to stop this migration from East to West is both futile and not in the national interest.

It's futile because decisions to move are individua or household decisions. The choices are not based on whether or not a strip mine is allowed to open or whether or not a reclamation project has been approved by Congress.

I think many people tend to move first and find jobs afterward And in the West, jobs are available.

Secondly, "Snowbelt" Congressional moves directed at "keeping the other guy down" by voting against reclamation projects are self-defeating on a local and national level. Ultimately, this affects prices for things that all consumers need, such as beef, bread, lettuce and other produce, dairy products, oil, gas and coal.

1 "The Future of Water and the Bureau of Reclamation," by JF Coates, Inc., Washington. D C 
The West is not competing with the East for thıngs that can best be produced in East, such as steel. textiles, automobiles, and so on

But the West can make tremendous contributions to the country as a whole in food, copper, coal, oil, lumber, and high technology.

As former Colorado Governor John Love said, "The only limit to the future is the availability of water."

This brings me to the second point - decreased federal funding for reclamation projects.

I understand and sympathize with President Reagan's directions to cut federal spending. Yet I am concerned when the cuts are directed at programs that will pay for themselves many times over the original cost. I consider reclamation projects to be federal investments, rather than federal spending

Since 1902, the U.S. Government has invested only $\$ 10$ billion in reclamation projects. These projects serve about 10 million acres of land. That's an investment of about $\$ 1,000$ per acre during the past 80 years, for an average of $\$ 12$ a year per acre.

During the same period, reclamation projects have produced $\$ 100$ billion in benefits, such as crops, electrical power and taxes. That's an average return of $\$ 120$ per acre per year.

Western reclamation projects already have returned more money to the Treasury than they have taken out; and most of the projects will go on paying for decades.

\section{"Western reclamation projects alveady} have returned more money to the Treasury than they bave taken out; and most of the projects will go on paying for decades."

In 1978 alone, reclamation projects generated \$8.5 billion in private income, $\$ 1.7$ billion in corporate profits, $\$ 2.2$ billion in federal taxes and $\$ 11$ billion in state and local taxes.

The area served by reclamation projects is not large. There is a total of $10,093,000$ reclamation acres. That is only 15,770 square miles, an area that is about half the size of the State of Maine. Imagine what is possible for the future!

And the future does not just belong to farmers

During 1980, reclamation projects provided water to 22.1 million people. Some 19 million of these were municipal and industrial customers. The remaining 3.1 million were tarmers

My organization, the Salt River Project in Phoenix, Arizona, is the oldest reclamation project in the nation I think it is also a good case study on how reclamation development occurs.

In 1903. Phoenix was a dusty, little farm community in the midst of a seven-year drought. Irrigation had been practiced for about 35 years. When the Salt River flowed, canals carried water to about 200,000 acres of land, helping to produce almost every major kind of truit, vegetable and grain that can be grown on this planet.

But by the fitth year of the drought, thousands of acres of land were parched, thousands of acres of fruit trees were dead or dying and hundreds of people had left the valley.

Those that stayed included my grandparents, and they worked for passage of the Reclamation Act.

The first beneficiaries of the project, which was to grow to 238,000 acres, were some 3,500 farmers. These people used their private land as collateral for a $\$ 10$ million government loan to build dams and electric facilities and to improve canals. Other beneticiaries included the remaining 18,000 people in the county who had business ties to the farm community

Revenues from electric power sales to the copper mining industry were used to help hold down water assessments and to repay the government loan.

By 1940, the original loan was more than half-paid. and Phoenix had a population of 65,400 . In 1950, Phoenix reached a population of 106,800; and in 1955, the original loan was repaid in full.

Following World War II, tarmers accelerated their land sales to subdividers and industry. More than 280 manufacturing enterprises were started in Phoenix between 1948 and 1960. By 1960, Phoenix had a population of 434,200 . The important thing is this as the land changed uses, the water rights stayed with the land and were used for municipal and industrial purposes.

Today, Phoenix is the ninth largest city in the United States in population. More than one million people receive domestic water through the Salt River Project, which is about 60 percent "urbanized"

Now, some people think that a fully-urbanized project area will result in surplus water that can be used for municipal and industrial purposes. This is not true

We have kept careful records over the years, and have found that while land use has changed, water use has remained relatively constant. About two-thirds comes from the reservoirs. The remainder 
comes from groundwater pumping.

A recently-completed study shows that as population density increases (with the construction of townhouses and apartments), per-acre water use increases.

The bottom line is that when the project area is fully urbanized by 2034 A.D., some groundwater pumping will be necessary to offset the annual deficit in reservoir water. However, the deficit can be reduced through an active water conservation program (which we are sponsoring) and through development of additional water resources

I understand that this pattern of development farm to city - is occurring in other reclamation projects in the West.

Decreased federal investments in reclamation projects will not merely impact a handful of farmers rather it will touch on all citizens of the West - and to some extent to all citizens in the nation.

Additional water supplies will have to be developed to meet the growth that will continue to occur. If that has to be done with state or private capital, so be it The difference will be reflected in the cost of water and the cost of products developed with that water. Some farmers will not be able to compete with produce grown in established projects with lower-cost water, so I can see this water being used for municipal and industrial consumption, especially in the mining and energy industries.

And this brings me to my third point - increased competition among water users for existing and future supplies of water.

Already there are indications of this, where cities, mining, and energy companies sprout up alongside irrigated agriculture. The typical outcome is for mining or energy companies to retire farmland and transfer the water rights to the new development. This is not so harmful because usually these kinds of companies have enough capital to buy the land and acquire the water.

It's entirely different when a city is involved because municipalities have to sell bonds, raise taxes, or do both to achieve the same thing. Politics - in the worst sense of the word - comes into play, and many a speech is made about "farmers" versus "urbanites." Ignored is the fact that the farmers developed the water in the tirst place.

In conclusion, I think two steps need to be pursued by everyone concerned with the future of the West.

First, there has to be an ultimate determination of surface water rights. What is private, state, and iederal?

Second, the people of all the Western states have to continue working together to determine which reclamation projects should be built and then to build them - with or without federal loans.

These are not easy tasks, especially in the glare of national attention that is bound to occur. But they must be done, and we can succeed.

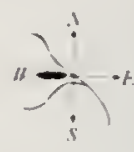






Sut intends to promote the general welfare of those dependent on the nation's rangelands through improved productivity. Those lands, where the natural vegetation is grassland, open forest, woodlands, or shrublands, comprise more than 60 percent of the 50 states. Nearly two-thirds of these rangelands are privately owned and all are grazed by domestic and/or wild animals. Rangelands are unsuited for cultivation but produce a great volume of forage that ruminant animals convert into high quality food protein. While this paper is directed toward domestic livestock and food production, let it be abundantly emphasized that rangeland management simultaneously aims for enhanced wildlife populations, covered watersheds, recreational opportunities, aesthetic values, protection of threatened and endangered species and reduced hazards from erosion and flooding.

Rangelands contribute to the food producing system in intimate association with other agriculture Livestock harvest some 100 million animal-unit-months (AUM) of rangeland forage each year. An AUM is the amount of forage needed by a mature cow for one month or an equivalent amount for other animals. Western-wide statistics are unavailable but the California example typifies the importance of rangeland grazing. It is estimated that 69 percent of the state's stocker cattle, 61 percent of its breeding beef cattle and 51 percent of its sheep are produced on rangelands. Most beef cattle production in the West seasonally uses rangelands combined with periods on planted forages, crop aftermath, harvested feeds, and agricultural by-products. Many animals are fattened on feed grains before slaughter. Thus, range animal production is closely linked to cropland agriculture

One frequently hears about the deteriorated condition and low productivity of both public and private rangelands. Private groups and even the land management agencies sometimes state that western rangelands are in poor condition and getting worse. Data from recent studies indicate otherwise. Between 1935 and 1976 the percentage of excellent and good condition ranges increased from 16 to 31 percent while fair and poor condition ranges made a corresponding decrease. Condition ratings evaluate the current status of the resource in relation to its productive potential. Much less range is in poor condition now than in 1935. A 1980 inventory found that about 7 percent of the western rangelands had critical and severe erosion while three-fifths were stable or with slight erosion. Clearly, more, much more, range conservation needs to be accomplished, but just as clearly, improvement is more prevalent than deterioration. Many in the range profession believe that livestock carrying capacity can be doubled from what it is today when the ranges reach full productivity under intensive management. They also believe that range sites and habitats can be improved for all the multiple uses at the same time. Large scale examples of successful range improvement programs exist in the western states. They have taken time, tinancial support, application of considerable scientific knowledge, and common sense. However, constraints of considerable magnitude continually increase the time and costs for range improvement. Some of these constraints, which limit even more progress and that need examination in the governmental arena, are as follows: 
First, increased intensity of rangeland use and management must look ahead to declining inflation, increasing real growth in the national economy, and more competition for available resources. Tight money forces both government and the range grazing industry into application of cost-effective practices Unfortunately much remains to be learned and understood in this area. The costs and returns to produce an AUM of grazing can be reasonably determined, but the costs and benefits of a visitor day, the value of one more deer, or an acre-foot of quality water are less readily determined When these multiple resources are considered in trade-offs with each other, it often seems that little gets done to enhance the total value of the resources. Although of unquestionable value, the preparation of environmental impact statements on rangeland use and management have also drained funds away from managing the resources. Governmental support funds have decreased and ranchers are in a situation where production costs increase faster than prices of livestock products. There is no question that people have sutfered, but so has the land resource improvement program. It is time for action to increase the real productivity of rangelands.

My second point is that expensive energy will encourage more effective grazing management of the nation's rangelands. It is well established that the land used for cultivated pastures is being converted to crop production and the remainder receives less fertilizer and irrigation than formerly, hence a lower grazing capacity than a few years back. High land and production costs, mostly energy and equipment, force cultivatable land to be used for the crops of greatest income. Fossil energy in the beef production system primarily produces feed to be fed mechanically to livestock through the use of farm and teedlot equipment. The production of rangeland forage uses less fossil energy than any other type of animal production and takes place on land unsuitable for crops. Ruminant animals convert low value rangeland forages into high quality human foods. Therefore, an increasing competitive advantage of rangeland grazing versus other forages is predicted This will require more intensive land management and animal husbandry than decades of teaching and preaching have accomplished in the past. If this prediction comes true, much research and organization of knowledge are needed to attain low energy costs and protitable food production trom rangeland

The third point is the need for mitigation of the impacts of local people when public decisions result in net gain for the public as a whole. This principle, when applied to the shifts in uses of rangeland, states that the gainers can compensate the losers and still be better off. An example of this problem is illustrated by the gains to the public and the losses of livestock when control of predators was restricted. Another recent example is the controversy over jackrabbit control to reduce damage to crops and range vegetation. Most everyone accepts the principle of equity, but few agree who should pay how much to whom and often disagreements occur over who has the rights in the first place. This issue should be decided based on comparative valuation of forage for livestock, water used off site, wildlife, and recreatıonal experiences. Such a mixture of values cannot as yet be precisely determined or fairly compared. These complex pricing problems require the best of research from the biological and social scientist, a spirit of compromise from the users, and full exposure in politcal discussion. The nation's political bodies have a high stake in these controversies through passage of laws and regulations, and support of management and research dealing with complex mixes of land ownership.

Lastly, I want further to emphasize the needs for rangeland research. Since 1976, 15 different documents that recommend research priorities for rangeland problems have come to my attention. One has only to examine an environmental impact statement to realize that our knowledge is inadequate to prepare for the kinds of problems currently faced by rangeland managers. People demanding use of rangeland resources have increased in numbers, but the bulge in rangeland research tollowing Sputnik has tapered off. For example, the number of scientist years devoted to forestry, range, wildlife and water research in California was 143 in 1958, 205 in 1968, and 155 in 1977 It is still less today. The cost per scientist year has doubled since 1958. There is less land, less water. less energy, and less food on this earth tor each of us than just a year ago. The current federal budget turther reduces our ability to produce lood at some later date by restricting research support now

The environmental syndrome, above all, has increased the unknown part of our knowledge storehouse because it asks for information we don't have. Oversimplitied, it is as tundamental as changing the emphasis from research making the cow more productive to research also finding how the cow can be used to make the whole rangeland more productive. Much remains to be done to make rangeland produce the food that it can and the amenities that it also can provide. 




\begin{abstract}
A
range of agricultural finance issues are currently of interest both to farmers and to public policy makers. The importance of many issues has been heightened by the farm recession. Some issues, however, emerge primarily from the changing economic and financial environment in which farmers now operate Still others are broad issues affecting both urban and rural Americans, but bearing on farm financial well-being This paper addresses the changing economic environment and identifies agricultural tinance issues of major importance to the private and public sectors
\end{abstract}

\section{THE CURRENT ECONOMIC ENVIRONMENT}

Agriculture is currently undergoing a period of considerable financial stress. That circumstance will likely continue at least through 1982, the third year in a row of depressed farm income (Chart 1). Some farm product price problems are related to excess supply - as in the case of food and feed grains. But more importantly, the current farm recession has an important demand side component, as weak economic performance, here and abroad, has limited growth in demand for U.S. farm products.

The nature of the current farm recession is best understood, however, in a broader context than is true for a cyclical downturn. The financial stress evident in U.S. agriculture has its roots in a number of fundamental changes in the economic environment in which farmers operate.

\section{Farm Programs}

Since the Great Depression, public policy has placed a safety net under farmers Policy has become more market-oriented over the past two decades. But, a more rapid adjustment now appears underway as the safety net across a broad range of programs, from disaster payments for crop producers to related dairy price supports to emergency credit programs, is being reduced. In its place, long-run government policy will place more emphasis on market development and on the response of farm production to market incentives. While this may be a prudent direction tor policy, in the short run the cutbacks in assistance have occurred before the benefits of the long-run policies are apparent. Thus, farmers who made business decisions premised on continued government assistance may find those decisions to be incorrect in light of the new policy environment.

\section{Price Inflation}

During the past two decades, farmers and nonfarmers alike have come to expect increasing rates of inflation - and until 1981, that expectation was usually validated by price increases. As a result, farm management and growth strategies changed Increased amounts of debt capital were used by farmers since it could be paid off with ever cheaper 




dollars. Moreover, the cost of carrying debt declined as the real rate of interest (before taxes) fell to near zero and occasionally below zero during the decade of the 1970s.

Concurrently, the value of farm land rose at rates in excess of inflation, in response both to inflation and to periods of favorable farm income. Many farmers purchased land with debt capital, counting on inflation to build an equity cushion in the property. Indeed, the rapidly rising land values permitted farmers to use such unrealized capital gains for refinancing operating debt - thus masking the impact of deteriorating farm income during the mid-1970s and the early 1980 s.

With the onset of concerted efforts to bring intlation under control, the prices of farm land are no longer appreciating more rapidly than inflation. In 1981, farm land prices declined 1 percent nationally according to the U.S. Department of Agriculture. Tenth Federal Reserve District data suggest greater declines in that region of the country (Table 1). Thus, farmers' ability to refinance debt by using land equity is being reduced. Additionally, the cost of carrying debt has increased dramatically with both nominal and real interest rates having reached record levels.

\section{Export Market Growth}

U.S. farmers and agribusinessmen engaged in a sustained program of capital investment during the 1970 s in order to take advantage of expected export market growth. Agricultural producers in other countries did the same. But, a combination of factors has slowed export market growth in the early 1980s. Slower economic growth in developed and developing countries of the world, higher value of the U.S. dollar in exchange markets, concerns over the credit worthiness of Eastern European countries, and deterioration of detente with the U.S.S.R. have all tended to reduce U.S. market opportunities. Greater competition from other exporting countries has cut into U.S. markets, as well. Thus, it now appears that for at least the first half of this decade U.S agriculture may have excess production capacity.

\section{Energy Pricing}

U.S. agriculture is in transition from low cost energy to relatively high cost energy. While the U.S. adjustment to world oil prices is complete, natural gas prices will escalate substantially by the mid-1980s. 
This transition is affecting farm cultural practices and tertilizer usage. It also promises to hasten the transition of some areas of irrigated agriculture to a less intensive type of production.

\section{THE FINANCIAL ISSUES}

A number of financial issues are important to U.S and to western agriculture.

\section{Cost of Money}

Foremost among issues in many farmers' minds is the cost of money. Interest rates, high as a result of macroeconomic policies to reduce inflation, have not yet declined as inflation has declined. It seems likely that financial market fears over prospective federal budget deficits have played an important role in holding the prime rate far above the current rate of inflation. If the fiscal policy dilemma is resolved and the pattern of prospective deficits turned decisively downward, interest rates could decline significantly. Without a satisfactory resolution, the rates may remain high by historical standards.

For farmers, increases in the cost of money have been particularly unsettling. In the past, agricultural banks typically generated loanable funds and wrote loans within a local market. Thus, farmers tended to be partially protected from fluctuations in national money market interest rates. With the passage of the Monetary Control Act of 1980, and the introduction of new market instruments, agricultural and other community banks were quickly drawn into the nation's broader financial markets. As a consequence, farmers now pay market rates for loan funds and receive market rates on savings.

\section{Competition for Loan Funds}

The integration of agricultural banks into national financial markets, along with the outstanding success of the Farm Credit Banks in raising loan funds in national markets, has assured farmers of access to credit when needed - providing the loan request is credit worthy. However, competition in national markets and the deterioration of long-term capital markets - a consequence of rapid price inflation have raised the cost for loan funds. Thus, large investments requiring a great deal of debt capital,such as land purchases, irrigation development, intra-structure investment, etc., will come under greater scrutiny by both borrowers and lenders.

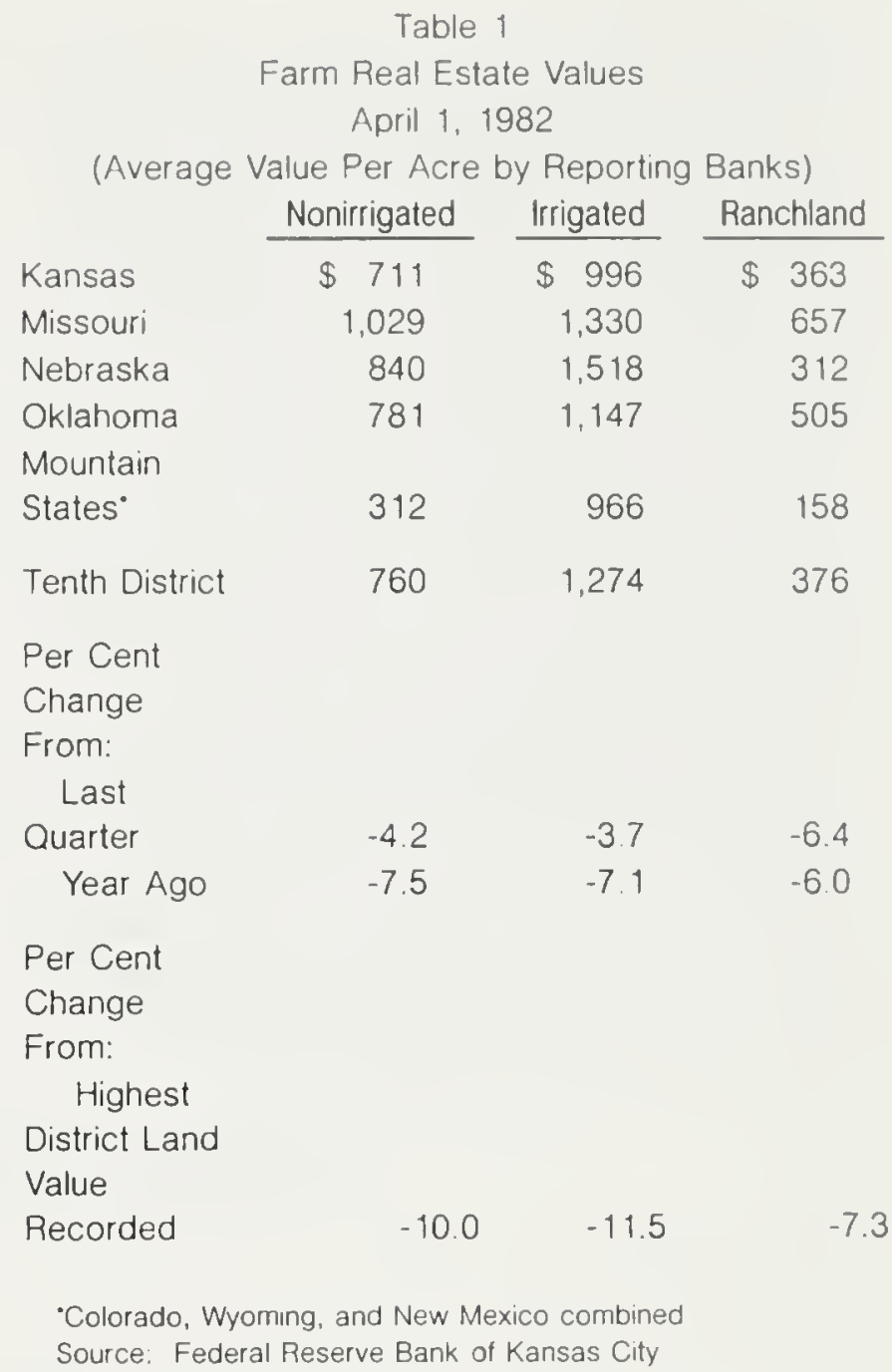

Continued large federal government deficits will, of course, add to the competition for loan funds and to the prices paid for those funds.

\section{Volatility of Interest Rates}

Farmers and nonfarm businessmen, alike, have found the recent volatility in interest rates unsettling. While greater volatility is a consequence of current Federal Reserve procedures for implementing monetary policy, the amplitude of that volatility will likely subside as inflation declines, as uncertainty about the direction of macroeconomic policy is reduced, as market participants better understand Federal Reserve goals and procedures, and as deregulation of tinancial institutions is completed

Nonetheless, rates will likely continue more volatile than prior to 1979. A measure of that volatility tor agricultural loans is found in Chart 2. To better manage volatility, both borrowers and lenders may turn to financial futures markets to fix their cost of loan funds. 


\section{Financial Stress}

While the farm sector as a whole is weathering the current farm recession quite well, evidence of significant financial stress for some farmers and agribusinesses is emerging. Tenth Federal Reserve District agricultural bankers estimate that as many as 4 percent of farmers and ranchers in their trade areas may be forced from business this spring due to financial adversity. Agricultural bankers also indicate that a much higher proportion of farm and nonfarm loans are being carefully monitored by lenders. Not surprisingly, financial stress is most severe among those farmers and ranchers who are carrying heavy debt burdens recent entrants and those who have expanded the size of their business using debt capital.

If recovery in both the general and the farm economies is underway by year end, the number of farmers forced out of business by financial adversity although larger than in recent years - will be limited to manageable levels. However, if recovery is not in sight by that time, a substantıal increase is likely to occur in the proportion of farmers and nonfarm rural businesses with severe financial problems.

\section{The Role of Public Lenders}

Until recently, public sector lending to agriculture was the most rapidly growing component of farm debt Farmers Home Administration (FmHA) lending - which had grown more rapidly than other types of nonreal estate debt, primarily due to emergency lending programs - accounted for 151 percent of all non-real estate farm debt outstanding by the end of 1981. FmHA farm real estate lending accounted for 8.8 percent of all farm real estate debt outstanding at the end of 1981, as well. The rapidity of growth in such credit outstanding has caused Congress and the current Administration to markedly tighten the qualification requirements for such credit. As a result, farmers and private lenders are now essentially left to mutually work out their farm loan problems rather than to rely on government subsidized credit to ease the resolution.

\section{Export Competitiveness}

U.S. farmers enjoyed rapid growth in farm exports during the decade of the 1970s. However, export value in fiscal 1982 is expected to decline slightly for

\section{Chart 2}

\section{Tenth District Farm Loan Rates}

Percent

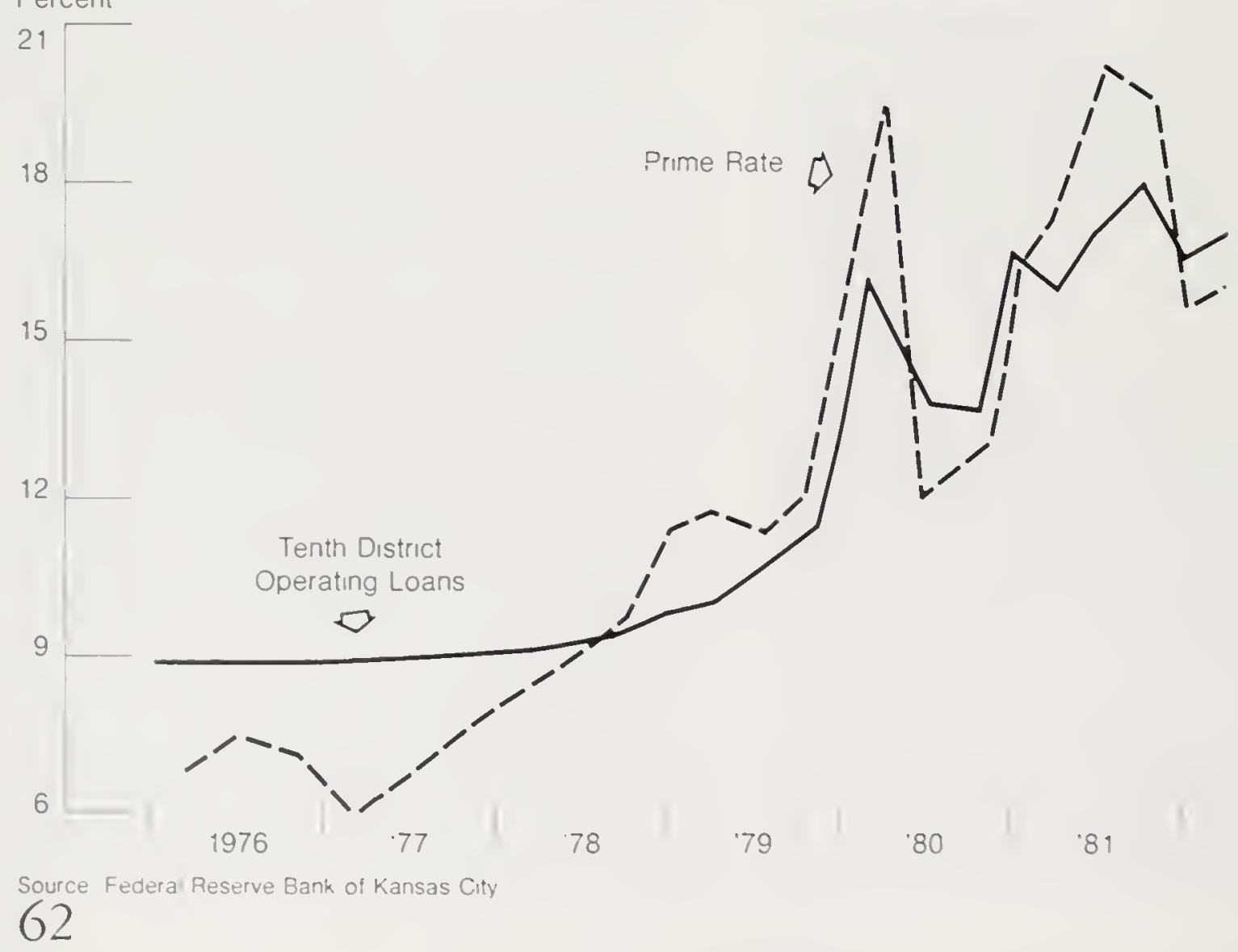


the first time since 1968 Since the production from more than one out of three harvested acres in the United States is being sold in the export market, such sales are extremely imporfant to agriculture's well being. Provision of additional government export credit and credif guarantees would facilitate the turther growth of sales. A reduction in the price of the dollar against the currencies of U.S. trading partners would also enhance U.S. compefifiveness in export markets.

\section{Financing New Entrants}

With a larger proportion of U.S. farm operators reaching retirement age during the next decade, greater numbers of new entrants may be entering farming. Facilitating their successful entry, along with the intergenerational transfer of farm businesses, will challenge financial institutions and public policy makers. It is likely that substantial innovation in tinancial arrangements will be required to enable new entrants to gain control of the resources to successfully enter the business.

\section{Nonfarm Investment in Agricultural Production}

With the growing capital requirements of U.S. agriculture, and lower farm profit margins, farmers have increasingly financed farm capital investment with debt capital. That, however, can present problems especially for new entrants. One solution to the dilemma of high capital demands would be for tarmers to acquire the use of equity capifal from off-farm investors, through pension funds, insurance companies, financial leasing, etc. Yet, farmers and public policy makers have often avoided a thoughtful, rational analysis of the role for these capital sources in modern agriculture

\section{Financing the Essential Public Infra-Structure}

The nation's agricultural sector has greatly benefited from past public investment in irrigation, flood control, power generation, waterways, and highways and bridges. There has been a retrenchment in such investments during recent years. Moreover, the issues of public versus private funding through user fees, as well as the appropriate level of public funding are as yet unresolved How these issues are decided will affect all of U.S. agriculture, but particularly that of the Western states.

\section{SUMMARY}

The resolution of these issues is important to agriculture's well-being. In some instances, public sector action may be appropriate. However, successful public policy solutions will depend on clear understanding of the root causes of the issues addressed. Recurring cyclical problems, for example, may require more permanent programs. However, problems related to a changing economic environment may warrant only short-term relief to aid in adjustment to that environment.






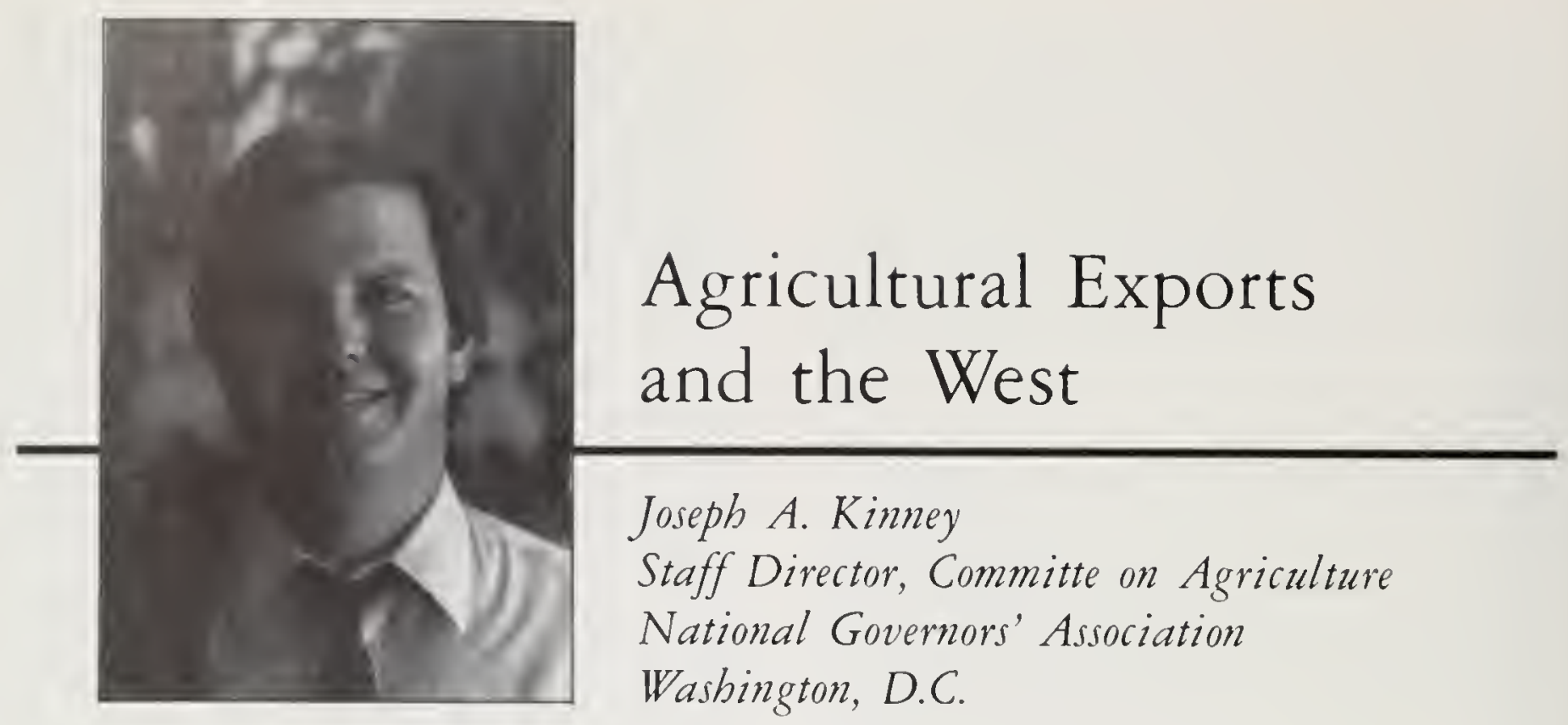

A economy of the western United States. As Table 1 shows, western states are important exporters of wheat, cotton, hides, meat, fruits, nuts, vegetables, and other farm products. Depending on a variety of factors discussed later, agricultural exports from the West could likely grow in future years.

It is generally known that agricultural exports are an important part of the U.S. economy. This year, we will export $\$ 42.5$ billion in farm commodities and products. In 1981, we exported more dollars worth of corn than any other product except jet aircraft

Today the jetstream of America's farm commodities can be lound in all corners of the globe. It is said that agriculture is America's export superstar. The facts bear out this contention. In 1981-82, we will export 77 percent of the soybeans sold on the world market, 74 percent of the corn. We also export 45 percent of the wheat and 34 percent of the cotton traded in the world.

There is little question that the opportunity to produce for the export market is a significant factor in the productivity of the U.S. farmer - productivity that has meant, among other things, the lowest retail food prices in the world for the American consumer State governments have recognized the significant role that the export market plays in the economic viability of the nation's 2.4 million farm and ranch families. Many western states have overseas trade offices and governors make marketing missions abroad, especially to Pacific Rim nations where markets are growing rapidly.
This interest is consistent with the dedication of state government to expand market opportunities abroad. The National Governors' Association, for example, has created an Agricultural Exports Task Force and the National Association of State Departments of Agriculture is planning regionally-located international trading expositions for our foreign customers.

In recent years Congress has passed critical legislation designed to boost foreign food and fiber sales.

In 1978, Congress passed the Agricultural Trade Export Expansion Act, the first significant trade expansion bill adopted by Congress in many years. Untortunately, Congress has yet to fully appropriate funding for the authority that is in this bill.

Most recently, Congress passed, as part of the 1981 omnibus farm legislation, a law establishing an export revolving fund for agricultural exports. The purpose of this fund is to provide a stable source of financing for farm exports. This legislation will help flatten the "funding curve" for export financing, helping the U.S. establish a foothold in middle income countries and help us maintain market shares against exporting nations that subsidize exports.

As such, a revolving fund is essentially a market development tool that is required to make significant inroads in the markets of the middle income countries like South Korea, Indonesia, and Chile. Many of the countries that fit into this category were once recipients of the Public Law 480 "Food for Peace" program. 
The Administration, led by Secretary of Agriculture John Block, has demonstrated very strong interest in promoting U.S. lood and fiber in the world market The U.S. Department of Agriculture has sent trade teams to Atrica, Asia, and South America in recent months, opening doors for US. food and fiber. These teams, which wisely have included individuals from the private sector, are identifying ways in which the federal government can be more effective in meeting the needs of these markets. This special private-public partnership will pay substantial dividends in future years.

The formula for future success in the area of agricultural exports appears to be dependent on a number of factors. These include:

(1) Public attitudes about the world market At present, most Americans do not understand the imporfance of exports to the state of the American economy. Without public appreciation, the private sector will not achieve its full market potential nor will public resources be effectively or efficiently utilized.

(2) Roadblocks to entry to U.S. firms in the world market

A more full partnership between the private and public sectors has to be developed in this area. Trade restrictions and the use of export subsidies must be curbed, reduced, then eliminated in order that we achieve an open global trading system

(3) Effective use of public resources in agricultural exporting

At present, there is the need to assure more careful cooperation and coordination between state and federal levels of government in promoting our products abroad This is essential in an era of tight funding for all levels of government. Another area of concern relates to the ability of the public sector to develop marketing strategies in new markets, while assuring maintenance of existing markets. Because of the complexity of agricultural markets and diversity in U.S. suppliers, the government must play an active role.

(4) Need for export trading companies in agriculture

At present, the grain trading companies and large export-oriented farm cooperatives are doing an outstanding job servicing the international market. However, there needs to be an effort made to provide smaller companies the economies of scale that are inherent in the trading company concept. These companies include small packers and agricultural processors. We need to learn from our global neighbors: the Japanese and Germans have used trading companies to penetrate markets throughout the world.

While water and soil will be limiting factors in the West's ability to export, the demand side of the equation looks bullish. The need for food and fiber should continue to grow and our margins in comparative advantage remain sizable. Our society has derived considerable benefits from our agri-abundance and the prospect for even more gains, especially if we can add value to commodities such as wheat, are promising. Western states are geographically situated to exploit some of the most promising markets - Indonesia, Korea, Chile, Venezuela - as well as to service one of our most vital markets, Japan.

Table 1 - Agricultural Export Shares for Western States from Fiscal Year 1981

\begin{tabular}{|c|c|c|}
\hline States $^{\circ}$ & $\begin{array}{l}\text { Million } \\
\text { Dollars }\end{array}$ & Leading Commodities \\
\hline Arizona & 488.3 & Cotton, Fruit, Wheat \\
\hline $\begin{array}{l}\text { Califor- } \\
\text { nia }\end{array}$ & $3,588.5$ & Fruit, Cotton, Nuts \\
\hline $\begin{array}{l}\text { Colora- } \\
\text { do }\end{array}$ & 779.5 & $\begin{array}{l}\text { Wheat, Feedgrains, Veg- } \\
\text { etables }\end{array}$ \\
\hline Hawaii & 58.6 & $\begin{array}{l}\text { Fruits, Nuts, Meat } \\
\text { Wheat, Vegetables, }\end{array}$ \\
\hline Idaho & 634.3 & Hides \\
\hline $\begin{array}{l}\text { Mon- } \\
\text { tana }\end{array}$ & 513.4 & Wheat, Hides, Meat \\
\hline $\begin{array}{l}\text { Nebras- } \\
\text { ka }\end{array}$ & $2,113.8$ & $\begin{array}{l}\text { Feedgrains, Wheat, Soy- } \\
\text { beans }\end{array}$ \\
\hline Nevada & 25.1 & Wheat, Meat, Fat \\
\hline $\begin{array}{l}\text { New } \\
\text { Mexico }\end{array}$ & 151.1 & $\begin{array}{l}\text { Feedgrains, Wheat, Cot- } \\
\text { ton }\end{array}$ \\
\hline $\begin{array}{l}\text { North } \\
\text { Dakota }\end{array}$ & $1,143.7$ & $\begin{array}{l}\text { Wheat, Sunflower, } \\
\text { Feedgrains }\end{array}$ \\
\hline $\begin{array}{l}\text { Oregon } \\
\text { South }\end{array}$ & 512.5 & $\begin{array}{l}\text { Wheat, Vegetables, Fruit } \\
\text { Wheat, Feedgrains, Soy- }\end{array}$ \\
\hline Dakota & 708.2 & beans \\
\hline Utah & 114.3 & Wheat, Hides, Meat \\
\hline $\begin{array}{l}\text { Wash- } \\
\text { ington }\end{array}$ & 1,0176 & Wheat, Vegetables, Fruit \\
\hline $\begin{array}{l}\text { Wyo- } \\
\text { ming }\end{array}$ & 93.7 & Wheat, Vegetables, Meat \\
\hline
\end{tabular}

-Data unavailable for Alaska

Compiled from data prepared by US. Department of Agriculture 


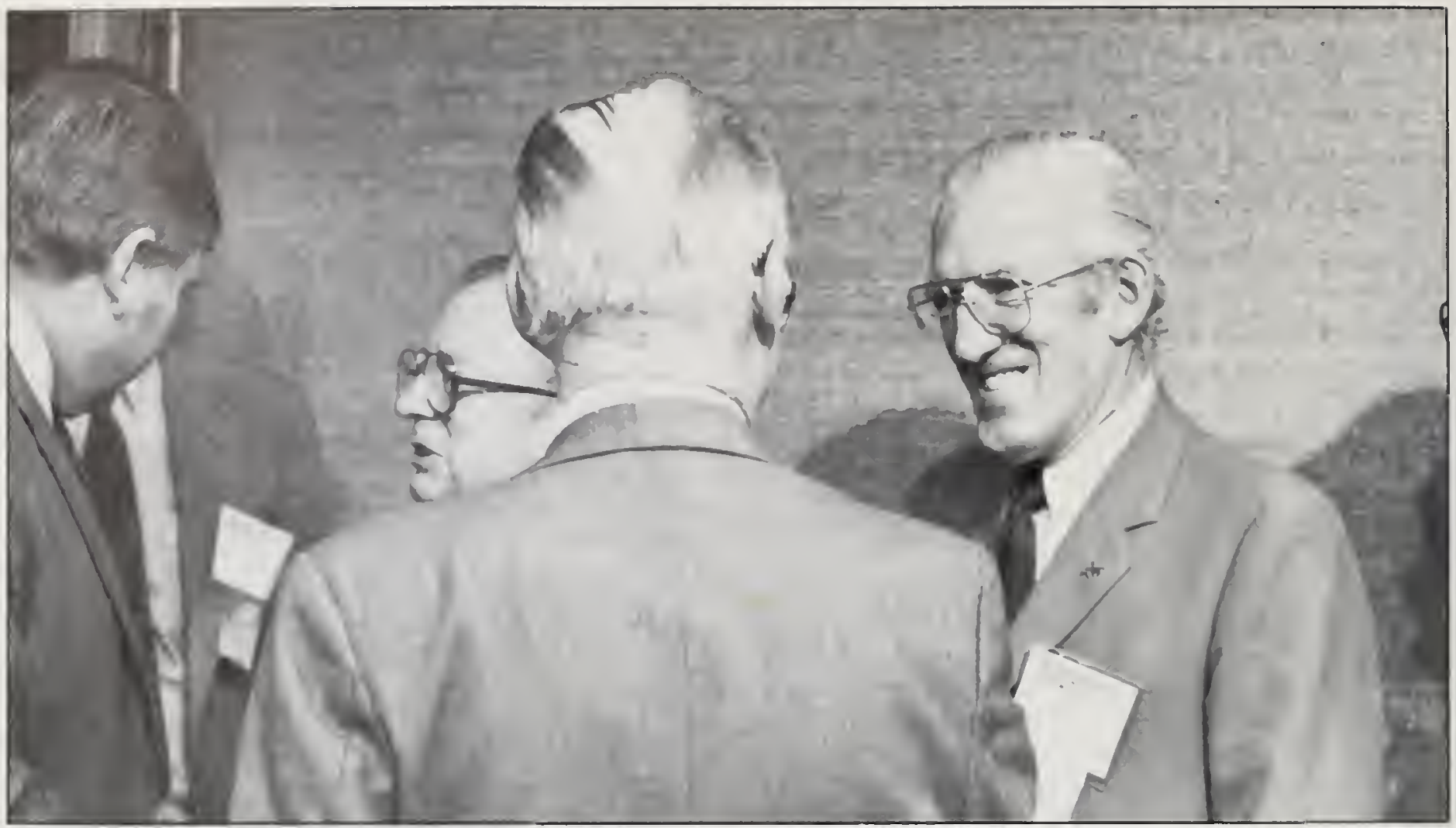

Gov. Ed Herschler, meets with participants. 


\section{Postscript}

During the business portion of the 1982 Western Governors' Conterence, Governor Ted Schwinden of Montana, co-moderator of the "Food in the West" session, submitted a resolution calling on the Conference to establish a task force on agricultural issues. The resolution, which was adopted unanimously, states:

WHEREAS, the program "Food in the West" was a major plenary session topic of the 1982 annual Western Governors' Conference meeting; and

WHEREAS, agriculture is the basic industry of the West and provides a major contribution to the positive U.S. foreign trade balance; and

WHEREAS, agriculture provides employment for over one half million farmers and ranchers in the West and comprises over twenty percent of the nation's total economy; and

WHEREAS, agriculture is a renewable industry that provides long-term economic stability to the region; and

WHEREAS, agriculture is suffering a third consecutive year of depressed prices and 1982 farm income is projected on levels of the 1930's, causing increased tarm foreclosures and bankruptcies; and

WHEREAS, tederal budget cutbacks are restricting agricultural research that will hamper our efforts to teed a world population that will double to 8 billion people by the year 2015; and

WHEREAS, the future of economic recovery in the U.S. will be significantly enhanced by a healthy agriculture economy

NOW, THEREFORE, BE IT RESOLVED that the Western Governors' Conference establishes a Task Force on Agriculture; and

BE IT FURTHER RESOLVED that the Conference calls for the Task Force to develop and present at the 1983 annual meeting of the Western Governors' Conference, a "Western Agricultural" program, including regional programs and strategies to strengthen the agricultural economy.

Subsequent to the completion of the Conference, Governor Schwinden was named Chairman of the Western Governors' Conference Task Force on Agriculture. A staff group is now working to examine issues that the Task Force and the Western Governors' Conterence should address in meeting the ever changing needs of our nation's most important industry. In the near future, the statt working group will present a work plan to Governor Schwinden and other members of the Task Force to meet this objective.

For more information

Please contact:

Joseph A. Kinney

Producer

Food in the West

National Governors' Association

Hall of States

444 North Capitol Street

Washington, D.C. 20001

(202) 624-5367 




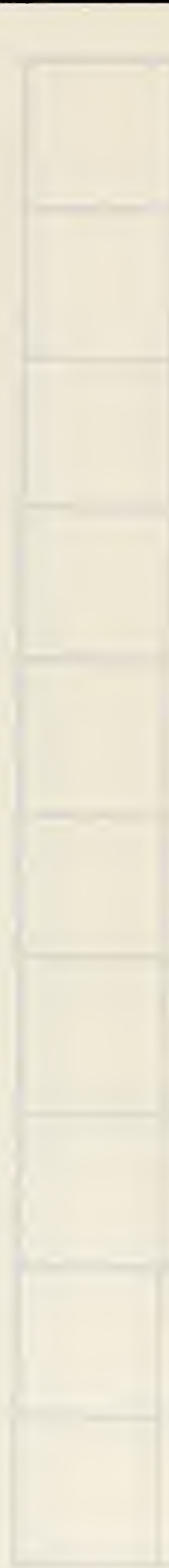

,

.
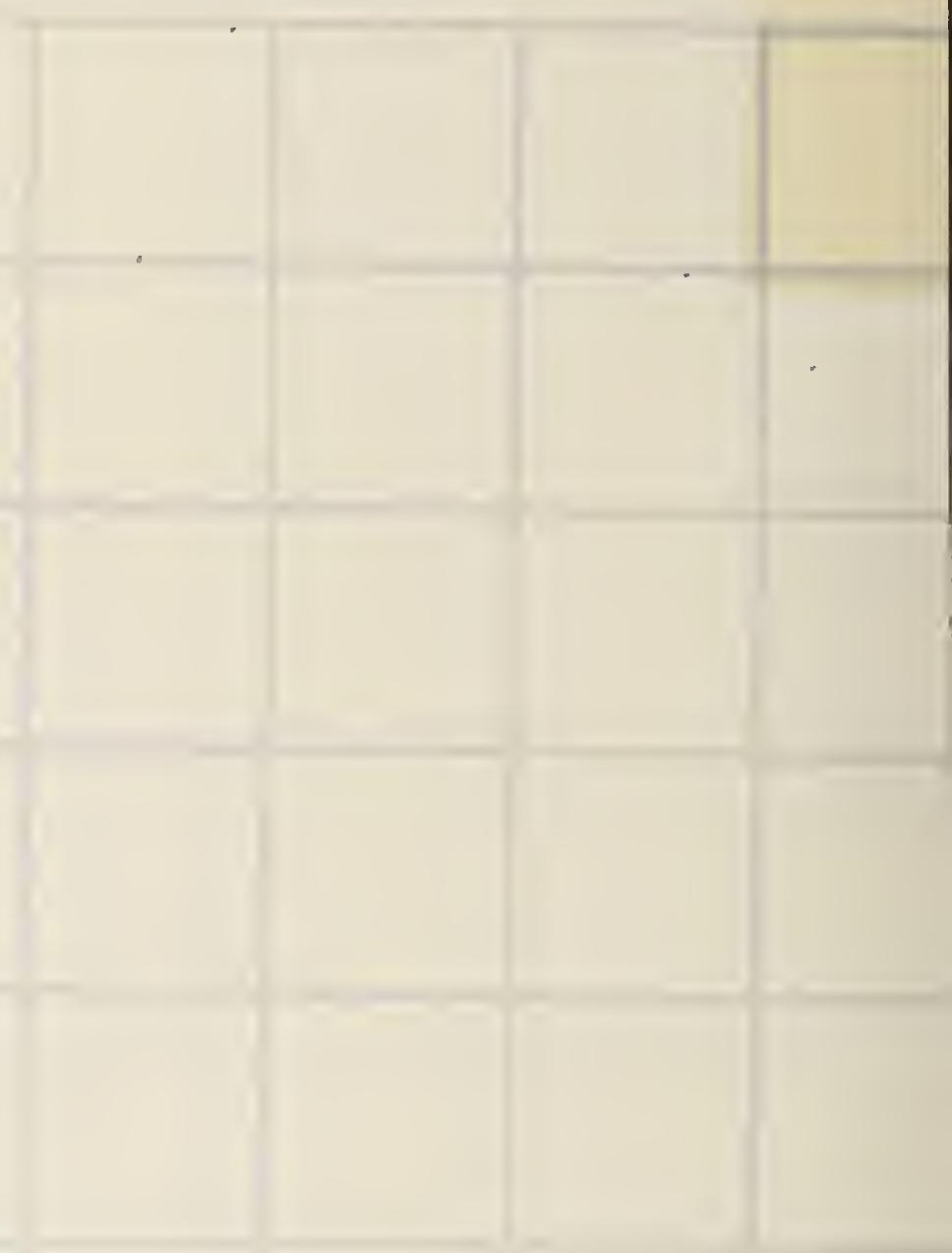